WAGNER CLAUDIO DA SILVA

ARGILA ORGANOFÍLICA COMO AGENTE MICROBIANO PARA TINTAS

SÃO PAULO

2012 
WAGNER CLAUDIO DA SILVA

\section{ARGILA ORGANOFÍLICA COMO AGENTE MICROBIANO PARA TINTAS}

Dissertação apresentada à Escola Politécnica da Universidade de São Paulo para obtenção do título de Mestre em Engenharia

Área de concentração:

Engenharia Metalúrgica e de Materiais

Orientador: Prof. Dr. Francisco Rolando Valenzuela Diaz

SÃO PAULO 
Este exemplar foi revisado e alterado em relação à versão original, sob responsabilidade única do autor e com a anuência de seu orientador.

São Paulo, de janeiro de 2012.

Assinatura do autor

Assinatura do orientador

\section{FICHA CATALOGRÁFICA}

Silva, Wagner Cláudio da

Argila organofílica como agente microbiano para tintas /

W.C. da Silva / W.C. da Silva. -- ed.rev. -- São Paulo, 2011.

$81 \mathrm{p}$.

Dissertação (Mestrado) - Escola Politécnica da Universidade de São Paulo. Departamento de Engenharia Metalúrgica e de Materiais.

1. Argilas 2. Sal quaternário de amônio 3. Algicidas 4. Tintas 5. Lixiviação I. Universidade de São Paulo. Escola Politécnica. Departamento de Engenharia Metalúrgica e de Materiais II. t. 


\section{AGRADECIMENTOS}

A Deus, por estar sempre ao meu lado, me dando benção e guiando;

Aos meus pais Tinho e Eliana, pelo apoio aos estudos;

Ao orientador prof. Dr. Francisco Rolando Valenzuela Diaz, pelo valoroso ensinamento para realização deste trabalho, pela confiança, paciência e compreensão para que eu atingisse meu objetivo;

A Alexandra Paschoalin, bióloga da Clariant, que me incentivou e contribuiu na elaboração dos testes microbiológicos e de lixiviação;

Ao Dr. Antonio Pedro de Oliveira Filho, químico da Clariant, pelo incentivo a iniciar o mestrado e por acreditar em meu trabalho;

A Valquíria, química do Laboratório de Matérias Primas e Sólidos não Metálicos (LMPSol) da USP, pelos ensaios de difração de raios X;

A Clariant S/A pela oportunidade de realizar este trabalho e concluir o curso de mestrado.

A todos que direta ou indiretamente contribuíram na realização desta pesquisa. 
"Não se tira nada de nada, o novo vem do antigo, mas nem por isso é menos novo". - Bertolt Brecht 


\section{RESUMO}

Sais quaternários de amônio são amplamente usados como agentes antissépticos, desinfetantes, detergentes e preservantes. Além disso, sais quaternários de amônio são frequentemente utilizados como algicidas, sendo o cloreto de dodecil dimetil benzil amônio (Cloreto de benzalcônio) o mais efetivo contra estes microorganismos.

No entanto sua aplicação como algicida de superfícies é limitada, devido a sua alta hidrofilicidade, ocasionando uma alta lixiviação deste composto quando a superfície é exposta à alta umidade e intempéries de clima tropical.

Atualmente compostos como Diuron e S-Triazina são empregados como algicidas, considerados de baixa lixiviação. No entanto, altos níveis de concentração destes biocidas foram detectados em regiões costeiras evidenciando a lixiviação destes biocidas, quando utilizados em tintas para casco de navio.

Assim surge a necessidade do desenvolvimento de um algicida para suprir as deficiências de lixiviação dos compostos empregados atualmente. Materiais como as argilas organofílicas são uma excelente alternativa, pois são altamente hidrofóbicas. Portanto sintetizou-se neste trabalho uma argila organofílica utilizando-se cloreto de benzalcônio, a qual foi utilizada em uma formulação de tinta imobiliária. O material foi caracterizado pelas técnicas de difração de Raios $X$ e análise termogravimétrica.

Um filme de tinta foi submetido a uma câmara de lixiviação, simulando a ação da chuva. Após a lixiviação o filme de tinta seguiu para testes microbiológicos, para verificar se a superfície ainda possui proteção microbiana. As algas testadas foram das espécies Phormidium cebenense, Trentepohlia odorata, Chlorella sp e Scenedesmus quadricauda colocadas num pool de algas.

Através das análises de Difração de Raios $X$ e termogravimétrica é possível determinar a estrutura e quantificar o teor cloreto de benzalcônio no material, respectivamente. Os testes microbiológicos e de lixiviação avaliaram a capacidade biocida assim como a resistência à intempérie do material. O novo composto sintetizado neste trabalho apresentou um alto potencial para uso como agente microbiano em tintas.

Palavras-Chave: Argila organofílica, Algicida, tintas, lixiviação. 


\section{ABSTRACT}

Quaternary ammonium compounds are widely used as antiseptic agents, disinfectants, detergents and preservatives. In addition, quaternary ammonium compounds are often used as algaecides, and dodecyl dimethyl benzyl ammonium chloride (benzalkonium chloride) is the most effective against these microorganisms.

However benzalkonium chloride is not used as surface algaecide compound due its high hydrophilic, bring on high leaching of this compound when the surface is exposed to high humidity and severe weather from tropical climate.

Currently, compounds such as diuron and s-triazine are used as microbial agent, considered low leaching. However diuron and s-triazine were detected in coastal regions in high levels concentration showing the leaching of these biocides when used in antifouling paints in ships.

Considering these, it can be observed the necessity to develop a new algaecide to overcome the failings of leaching of the compounds used nowadays. Material as organoclay is an excellent alternative because they are highly hydrophobic. Therefore in this work was synthesized a new nanomaterial using benzalkonium chloride, which was applied in a house paint formulation. The material was characterized by the techniques of X-ray diffraction and thermogravimetric analysis.

A film coating was placed in a leaching chamber, simulating the action of rain. After leaching the coating film was applied to microbiological tests to check if the surface still had microbial protection against the following algae species: Phormidium cebenense, Trentepohlia odorata, Chlorella sp and Scenedesmus quadricauda; placed in a pool of algae.

It was possible to determine the structure and quantify the amount of benzalkonium chloride in the material through X-ray Diffraction and Thermogravimetric analysis, respectively. The biocide capabilities as well as the resistance to weathering of coating with the material were analyzed by microbiological and leaching test, respectively. The new compound developed in this study has a high potential to be used as microbial agent in paints.

Keyword: Organoclay, Algaecide, paints, leaching. 


\section{SUMÁRIO}

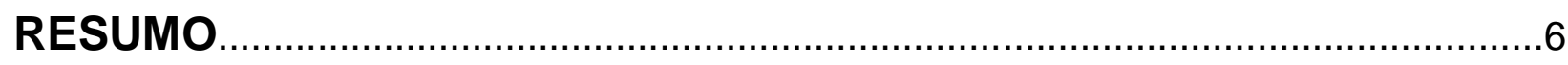

ABSTRACT

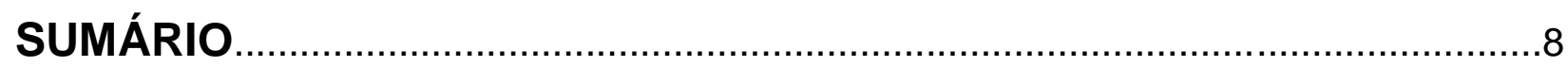

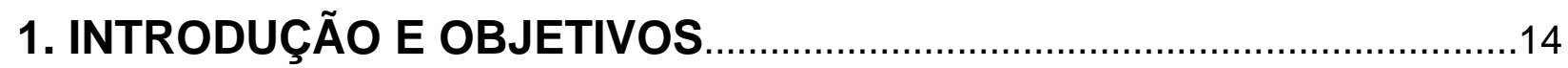

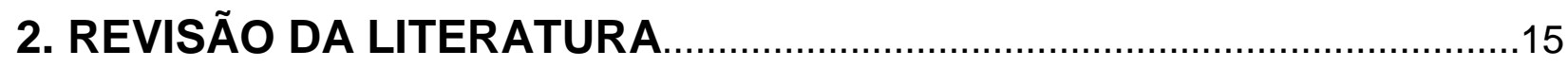

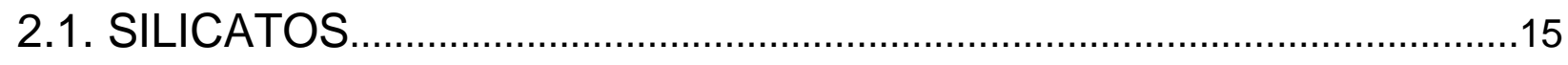

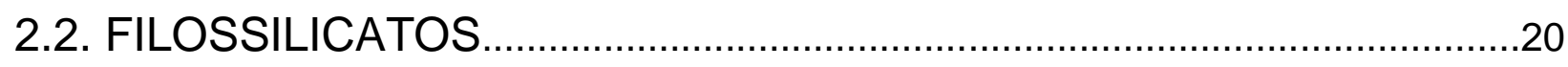

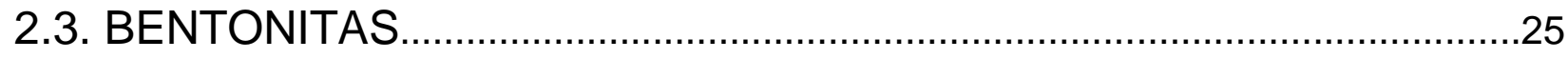

2.4. SAIS QUATERNÁRIOS DE AMÔNIO .......................................................29

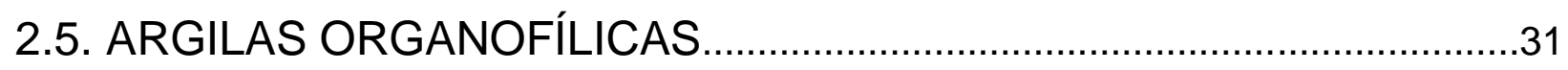

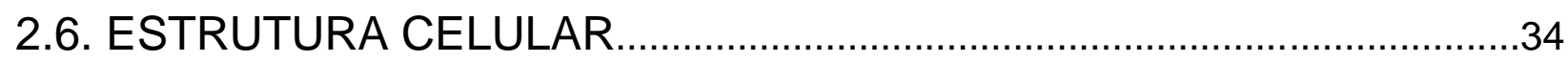

2.7. TRANSPORTE PELA MEMBRANA CITOPLASMÁTICA.....................38

2.8. AGENTES MICROBIANOS OU BIOCIDAS ..............................................

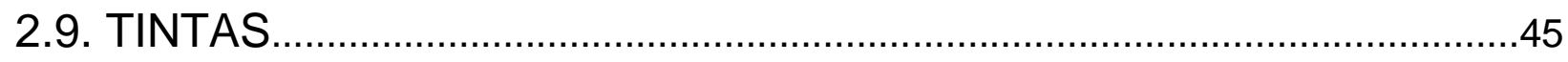

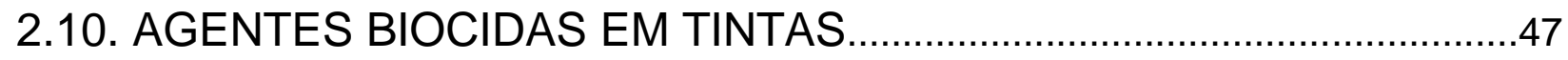

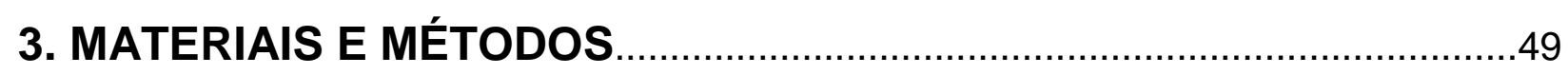

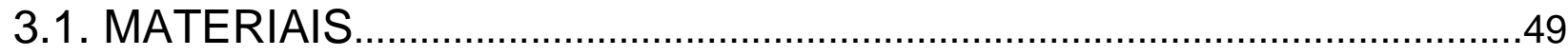

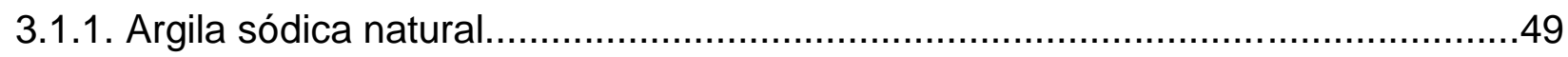

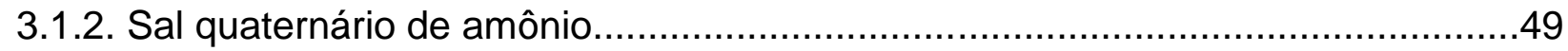

3.2. PREPARAÇÂO DA ARGILA ORGANOFÍLICA.......................................49

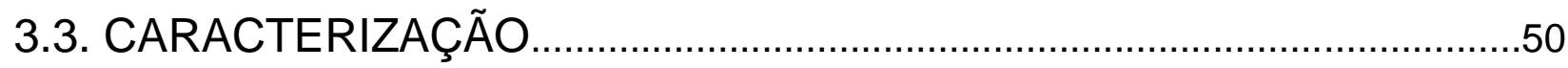

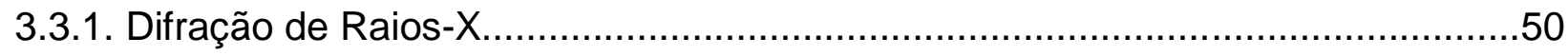

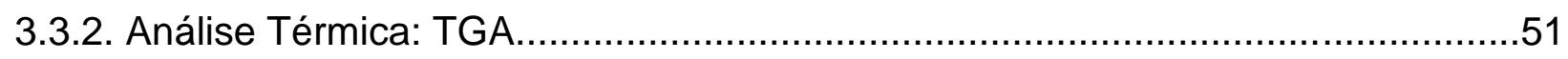

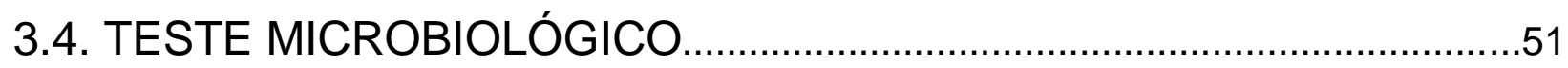

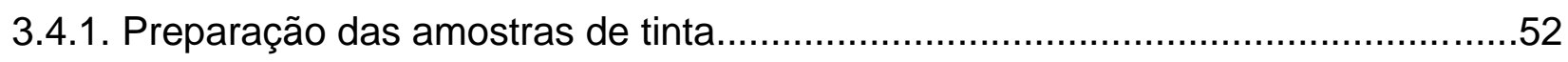

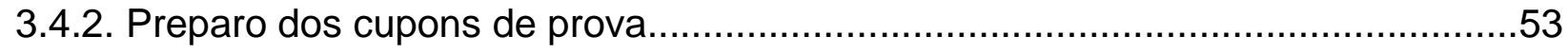


3.4.3. Teste de lixiviação dos cupons de prova.........................................................

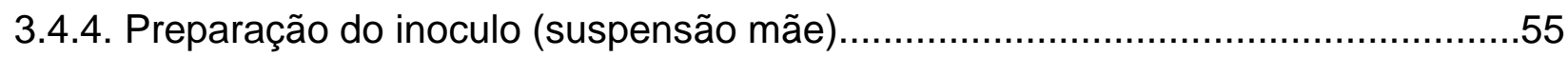

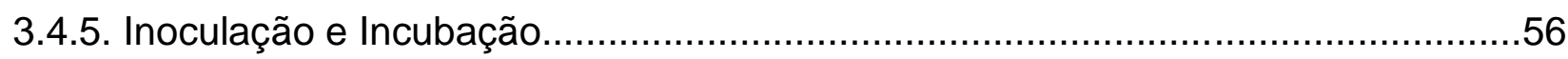

3.5. TESTE DE LIXIVIAÇÃO DE SUPERFÍCIE ..............................................56

3.5.1. Quantificação do sal quaternário de amônio.....................................................57

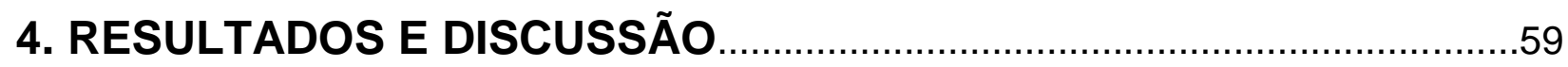

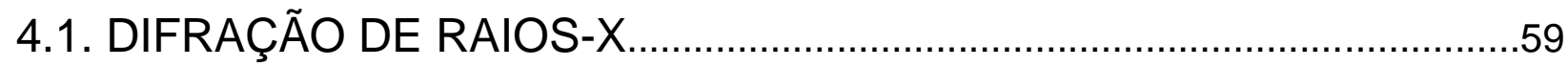

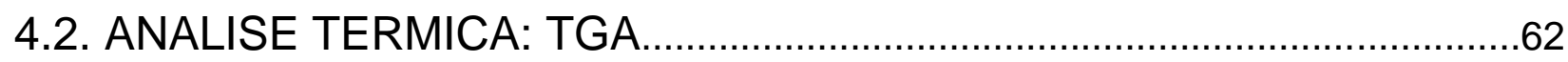

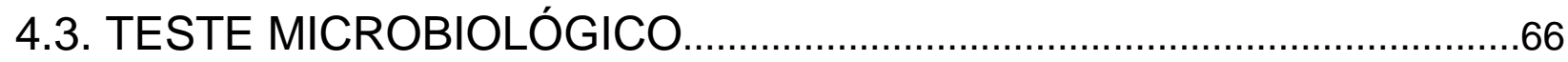

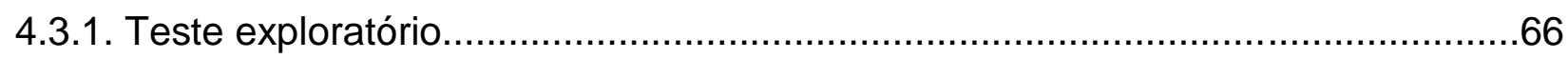

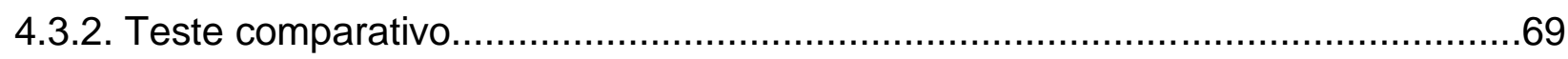

4.4. TESTE DE LIXIVIAÇÃO DE SUPERFÍCIE ...........................................71

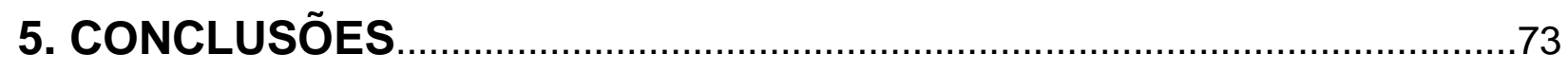

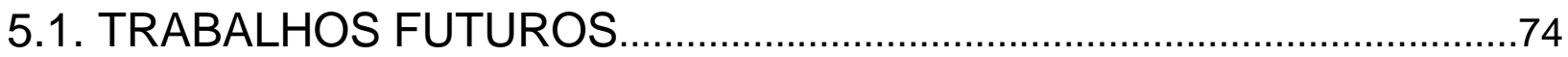

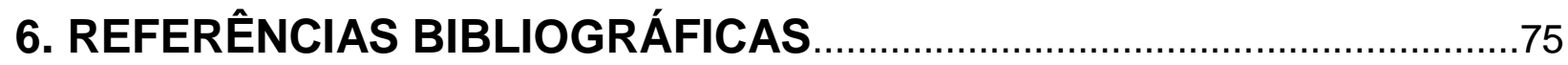




\section{LISTA DE ILUSTRAÇÕES}

Figura 1 - Grupos isolados $\left[\mathrm{SiO}_{4}\right]^{4-}$ (adaptado de BERGAYA et al, 2006)...................17

Figura 2 - Grupos isolados $\left[\mathrm{Si}_{2} \mathrm{O}_{7}\right]^{6-}$ (adaptado de BERGAYA et al, 2006)...................18

Figura 3 - Fórmula genérica $\left[\mathrm{Si}_{x} \mathrm{O}_{3 x}\right]^{2 x-}($ adaptado de BERGAYA et al, 2006)...............18

Figura 4 - Cadeia simples de inossilicato (adaptado de BERGAYA et al, 2006)...........19

Figura 5 - Cadeia dupla de inossilicato (adaptado de BERGAYA et al, 2006)...............19

Figura 6 - Estrutura planar do Filossilicato (adaptado de BERGAYA et al, 2006).........20

Figura 7 - Estrutura tridimensional dos tectossilicatos (adaptado de BERGAYA et al, 2006).

Figura 8 - Tetraedro de sílica e sua folha "T" e octaedro de alumínio e sua folha "O" (adaptado de JUNIOR, 2006).

Figura 9 - Estrutura lamelar da caulinita (adaptado de USGS, 2011)

Figura 10 - Estrutura lamelar da illita (adaptado de USGS, 2011).

Figura 11 - Estrutura lamelar da vermiculita - Mg (adaptado de USGS, 2011).

Figura 12 - Estrutura lamelar da montmorilonita (adaptado de USGS, 2011)

Figura 13 - Estrutura lamelar do talco(adaptado de USGS, 2011).

Figura 14 - Estrutura lamelar de uma clorita (adaptado de USGS, 2011)

Figura 15 - Estrutura lamelar da sepiolita e da poligorsquita (adaptado de USGS, 2011).

Figura 16 - Representação esquemática da estrutura das lamelas de uma esmectita (adaptado de COELHO; SANTOS, 2007). 
Figura 17 - Fluxograma de processamento de bentonita da Paraíba (adaptado de LUZ, 2005).

Figura 18 - Reação de uma alquil dimetil amina com cloreto de benzila gerando um cloreto de alquil benzil dimetil amônio.

Figura 19 - Fórmula geral para um sal quaternário de amônio.

Figura 20 - Representação de uma folha de esmectita (adaptada de BOTELHO, 2006)

Figura 21 - Mecanismo de organofilização de uma montmorilonita sódica (adaptada de LEITE, 2008).

Figura 22 - Variação do espaçamento basal $\left(d_{L}[\AA ̊]\right)$ de montmorilonitas modificadas com sais quaternários de amônio com diferente comprimento da cadeia alquilica (nc) (adaptada de PAIVA, 2008)

Figura 23 - Estrutura celular procarionte e eucarionte (adaptado de CARVALHO, 2007)

Figura 24 - Representação de uma célula eucarionte: 1.Nucléolo; 2.Núcleo; 3.Ribossomas; 4.Vesículas; 5.Retículo endoplasmático rugoso (RER); 6.Complexo de Golgi; 7.Microtúbulos; 8.Retículo endoplasmático liso (REL); 9.Mitocôndrias; 10.Vacúolo; 11.Citoplasma; 12.Lisossomas; 13. Centríolos (adaptado de CARVALHO, 2007) .35

Figura 25 - Representação do modelo mosaico fluido da membrana citoplasmática destacando seus principais componentes: glicolipídeo, glicoproteína, fosfolipídio, colesterol, proteína integrada e proteína periférica (adaptado de CARVALHO, 2007) 36

Figura 26 - Estrutura de um fosfolipídio (adaptado de CARVALHO, 2007)

Figura 27 - Funções das proteínas na membrana plasmática (adaptado de BIOLOGY, 2011) 38

Figura 28 - Funcionamento de bomba de sódio e potássio (adaptado de BIOLOGY, 2011)

Figura 29 - Mecanismo de ação de um biocida quaternário de amônio (adaptada de GILBERT, 2005).....

Figura 30 - Esquema geral do tanque de lixiviação. 


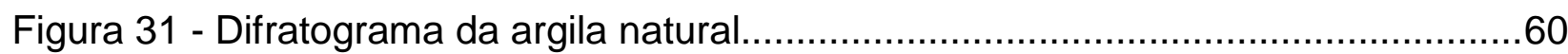

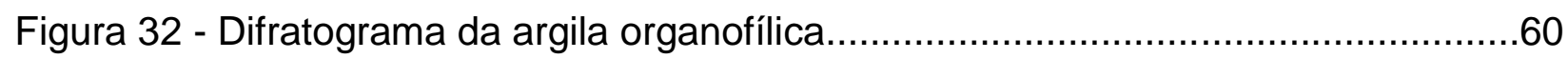

Figura 33 - Comparativo dos planos de difração (001) da argila natural e organofílica.61

Figura 34 - Análise termogravimétrica da argila natural..........................................62

Figura 35 - Análise termogravimétrica da argila organofílica.....................................63

Figura 36 - Análise termogravimétrica do sal quaternário de amônio...........................63

Figura 37 - Análise termogravimétrica comparativa..................................................64

Figura 38 - Foto do crescimento de algas sobre o corpo de prova do teste exploratório

Figura 39 - Foto do crescimento de algas sobre o corpo de prova do teste comparativo.......

Figura 40 - Filme de tinta recoberto de água (foto 40-A); Retirada de uma alíquota de água para quantificação do SQA (foto 40-B). 


\section{LISTA DE TABELAS}

Tabela 1 - Relação entre o sistema cristalino, número de coordenação, razão entre raios cátion-ânion e geometria da coordenação.

Tabela 2 - Componentes da formulação de uma tinta imobiliária.................................52

Tabela 3 - Observação do crescimento de algas sobre o corpo de prova......................56

Tabela 4 - Dados de Difração de Raios X da Argila Natural e Argila Organofílica..........61

Tabela 5 - Temperatura inicial $\left(\mathrm{T}_{\mathrm{i}}\right)$ e final $\left(\mathrm{T}_{\mathrm{f}}\right)$ de perda de massa $(\%) \ldots \ldots \ldots \ldots \ldots \ldots \ldots \ldots . . . .64$

Tabela 6 - Dosagem e escala de crescimento microbiano do teste exploratório...........67

Tabela 7 - Dosagem dos compostos adicionados na tinta para teste microbiológico...69

Tabela 8 - Escala de crescimento microbiano do teste comparativo.............................70

Tabela 9 - Quantificação do SQA no teste de lixiviação de superfície...........................72 


\section{INTRODUÇÃO E OBJETIVOS}

Argilas têm sido usadas pela humanidade desde a antiguidade para a fabricação de objetos cerâmicos, como tijolos e telhas e, mais recentemente, em diversas aplicações tecnológicas. A possibilidade de modificação química das argilas permite o desenvolvimento do seu uso para diversos tipos de aplicações.

Sais quaternários de amônio são um dos principais componentes utilizados para modificação e produção de argilas organofílicas. Além disso, sais quaternários de amônio possuem uma conhecida ação microbiana, sendo o cloreto de benzalcônio, o mais efetivo contra algas.

No entanto a utilização de sais quaternários de amônio como algicida para tintas é limitada, devido à alta hidrofilicidade destes compostos, ocorrendo à lixiviação do agente microbiano, especialmente em países de clima tropical, devido à alta umidade $\mathrm{e}$ intempérie. Os algicidas para tintas atualmente disponíveis no mercado apresentam um alto custo, toxicidade elevada além de serem lixiviáveis. As argilas organofílicas são uma alternativa com alto potencial, pois são altamente hidrofóbicas.

O objetivo deste trabalho é o desenvolvimento de uma agente microbiano para tintas não lixiviável.

Os objetivos específicos desta dissertação são:

(1) Sintetizar uma argila organofílica utilizando cloreto de benzalcônio e argila natural;

(2) Caracterizar o novo material através das técnicas de difração de raios-X e analise térmica (TGA);

(3) Avaliar a propriedade microbiana do novo composto sintetizado, em uma formulação de tintas, contra as algas Phormidium cebenense, Trentepohlia odorata, Chlorella sp e Scenedesmus quadricauda, antes e após a lixiviação do filme de tinta;

(4) Quantificar a presença de cloreto de benzalcônio na água de lixiviação do filme de tintas; 


\section{REVISÃO DA LITERATURA}

\subsection{SILICATOS}

Os elementos químicos oxigênio, silício, alumínio, ferro, magnésio, cálcio, sódio e potássio correspondem cerca de $98 \%$ da composição da crosta terrestre, sendo que destes o oxigênio e silício chegam à $70 \%$. Com isso entendemos porque os minerais que contem silício e oxigênio, denominados silicatos, são os minerais mais abundantes na crosta terrestre (VIANA, 2006).

As unidades fundamentais dos silicatos são os tetraedros formados pelos átomos de oxigênio e silício. A estrutura cristalina destes tetraedros é diretamente influenciada pelos raios iônicos dos cátions e dos ânions que constituem o material. O número de coordenação (isto é, o número de vizinhos aniônicos mais próximos para um cátion) está relacionado à razão entre os raios iônicos do cátion e do ânion. Para um número de coordenação específico, existe uma razão crítica ou mínima para a qual este contato cátion-ânion é estabelecido, cuja razão pode ser determinada a partir de considerações puramente geométricas. Considerando $R_{c}=0,42 \AA$, para o silício, e $R_{a}=1,40 \AA$, para o oxigênio, a razão $R_{d} / R_{a}$ será 0,30 (Numero de coordenação $=4$ ).

Além do silício outros cátions participam ativamente na composição da estrutura cristalina dos silicatos tanto substituindo o silício quanto agindo como elementos de ligação entre as unidades de tetraedros e octaedros. Entre esses cátions o $\mathrm{Al}^{3+}$ se destaca devido ao fato de ser o terceiro elemento em abundância na natureza e poder coordenar tanto 4 quanto 6 oxigênios. Isso é possível uma vez que a relação entre raios do $\mathrm{Al}^{3+}$ e $\mathrm{O}^{2-}$ de valor igual a 0,364 estar próxima de 0,414 valor mínimo para o número de coordenação seis. Os íons $\mathrm{Mg}^{2+}, \mathrm{Fe}^{2+}, \mathrm{Fe}^{3+}, \mathrm{Mn}^{2+}, \mathrm{Ti}^{4+}$ e $\mathrm{Li}^{+}$têm coordenação 6 com o oxigênio e formam soluções sólidas equilibrando as cargas elétricas, quando necessário, através de substituições conjugadas. O mesmo mecanismo de substituição conjugada ocorre com os cátions $\mathrm{Na}^{+}$e $\mathrm{Ca}^{2+}$ que têm maior raio iônico e número de coordenação 8 com o oxigênio. Os cátions $\mathrm{K}^{+}, \mathrm{Ba}^{2+}$, e $\mathrm{Rb}^{+}$, com coordenação 8 ou 12 , 
são também íons freqüentemente encontrados nos silicatos. A tabela 1 mostra o número de coordenação dos cátions mais comumente encontrados nos silicatos (KONTA, 1995).

Tabela 1 - Relação entre o sistema cristalino, número de coordenação, razão entre raios cátion-ânion e geometria da coordenação (adaptado de CALLISTER, 1991)

\begin{tabular}{|c|c|c|c|}
\hline $\begin{array}{c}\text { Sistema } \\
\text { Cristalino }\end{array}$ & $\begin{array}{c}\text { Número de } \\
\text { Coordenação }\end{array}$ & $\begin{array}{c}\text { Razão entre Raios } \\
\text { Cátion - Ânions }\left(\mathbf{R}_{\mathbf{c}} / \mathbf{R}_{\mathbf{a}}\right)\end{array}$ \\
\hline Linear & 2 & $<0,155$ \\
\hline Trigonal & 3 & $0,155-0,225$ & Geometria da \\
Coordenação
\end{tabular}


Da mesma maneira que a relação entre os raios iônicos condiciona a estrutura dos grupos aniônicos fazendo com que a estabilidade geométrica resulte no melhor empacotamento dos íons (íons os mais próximos possíveis), o equilíbrio das cargas iônicas também é um fator determinante significando que as cargas positivas e negativas devem estar balanceadas (CALLISTER, 1991). Os diferentes grupos de silicatos podem existir como tetraedros isolados, podem estar unidos por cátions ou unidos em estruturas mais complexas, através do compartilhamento dos oxigênios localizados nos vértices dos tetraedros. A classificação dos silicatos em grupos distintos é tradicionalmente feita em função das diversas possibilidades de compartilhamento dos íons de oxigênio e os diferentes arranjos de estruturas resultantes desse compartilhamento. Segue abaixo as principais características dos seis grupos de silicatos (BERGAYA et al, 2006):

Nesossilicatos ou Ortossilicatos: tetraedros individuais ligados por cátions não compartilhando oxigênio como a forsterita $-\mathrm{Mg}_{2} \mathrm{SiO}_{4}$. Os grupos isolados $\left[\mathrm{SiO}_{4}\right]^{4-}$ são mostrados na figura 1.

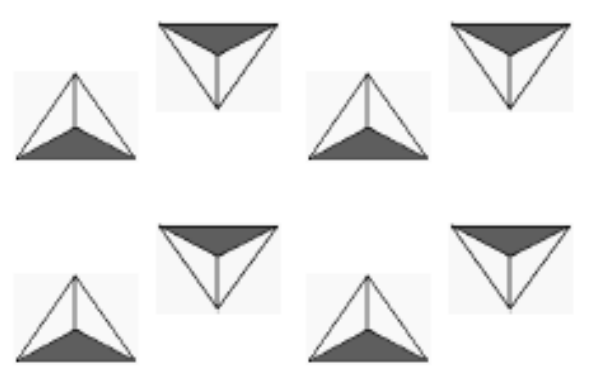

Figura 1 - Grupos isolados $\left[\mathrm{SiO}_{4}\right]^{4-}$ (adaptado de BERGAYA et al, 2006).

Sorossilicatos: dois tetraedros compartilhando um oxigênio levando a formação do grupo $\mathrm{Si}_{2} \mathrm{O}_{7}$ como a hemimorfita $-\mathrm{Zn}_{4} \mathrm{Si}_{2} \mathrm{O}_{7}(\mathrm{OH}) \cdot \mathrm{H}_{2} \mathrm{O}$. Os grupos isolados $\left[\mathrm{Si}_{2} \mathrm{O}_{7}\right]^{6-}$ estão ilustrados na figura 2. 


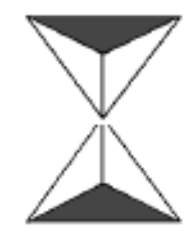

Figura 2 - Grupos isolados $\left[\mathrm{Si}_{2} \mathrm{O}_{7}\right]^{6-}$ (adaptado de BERGAYA et al, 2006).

Ciclossilicatos: mais de dois tetraedros ligados compartilhando um oxigênio e gerando uma estrutura em anel, figura 3 , como o berilo $-\mathrm{Be}_{3} \mathrm{Al}_{2} \mathrm{Si}_{6} \mathrm{O}_{18}$, fórmula genérica $\left[\mathrm{Si}_{x} \mathrm{O}_{3 \mathrm{x}}\right]^{2 \mathrm{x}-}$.

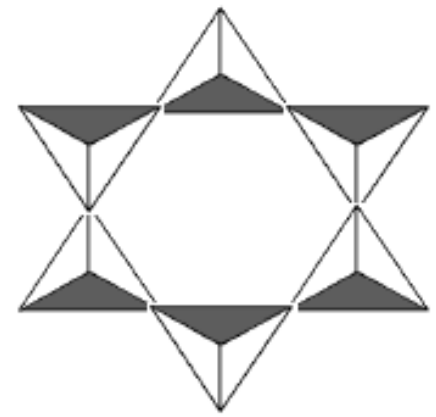

Figura 3 - Fórmula genérica $\left[\mathrm{Si}_{x} \mathrm{O}_{3 x}\right]^{2 x-}$ (adaptado de BERGAYA et al, 2006).

Inossilicatos: tetraedros ligados compartilhando dois ou três oxigênios e formando cadeias "infinitas". As cadeias são ligadas umas às outras por cátions. Os inossilicatos são classificados em inossilicatos de cadeias simples ou duplas.

Cadeias simples: cada tetraedro compartilha dois oxigênios formando uma cadeia, figura 4, como a enstatita - $\mathrm{MgSiO}_{3}$. A unidade básica é $\left[\mathrm{SiO}_{3}\right]^{2-}$ e as cadeias são ligadas umas as outras por cátions. Devido à essa cadeia, os inossilicatos tendem a formar cristais de forma alongada como no caso do espodumênio. 


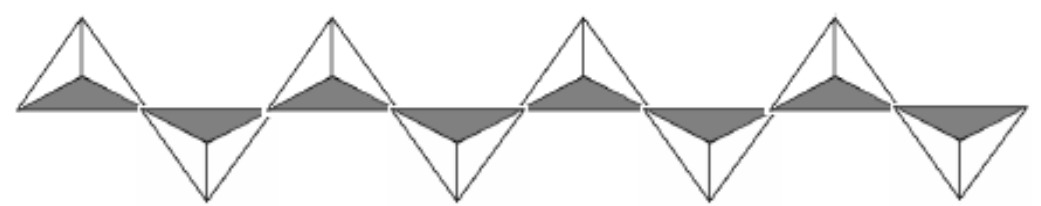

Figura 4 - Cadeia simples de inossilicato (adaptado de BERGAYA et al, 2006).

Cadeias duplas: cada tetraedro compartilha dois ou três oxigênios, figura 5, como a antofilita - $\mathrm{Mg}_{7} \mathrm{Si}_{8} \mathrm{O}_{22}(\mathrm{OH})_{2}$. A composição unitária é $\left[\mathrm{Si}_{4} \mathrm{O}_{11}\right]^{6-}$ e as cadeias são interligadas por cátions.

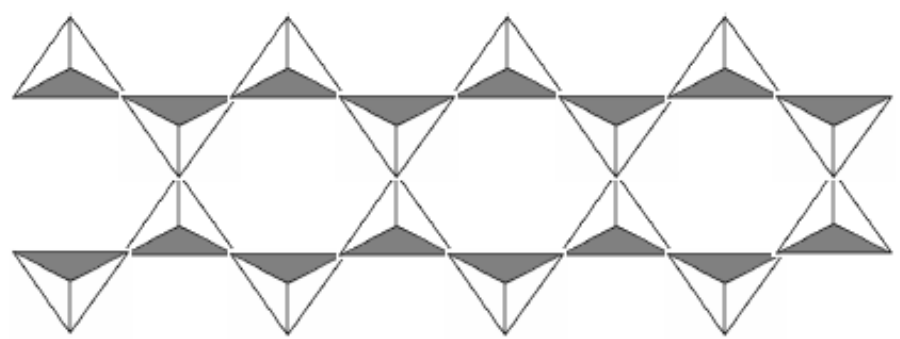

Figura 5 - Cadeia dupla de inossilicato (adaptado de BERGAYA et al, 2006).

Filossilicatos: tetraedros compartilham três oxigênios entre os tetraedros vizinhos formando estruturas planares "infinitas" (figura 6), como as micas e argilo minerais. $\mathrm{O}$ argilo mineral caulinita $-\mathrm{Al}_{2} \mathrm{Si}_{2} \mathrm{O}_{5}(\mathrm{OH})_{4}$ é um exemplo de filossilicato. $\mathrm{Na}$ maioria dos filossilicatos a formação e união de camadas são viabilizadas por cátions e grupos $\mathrm{OH}$, quando não há oxigênio para compartilhar. 


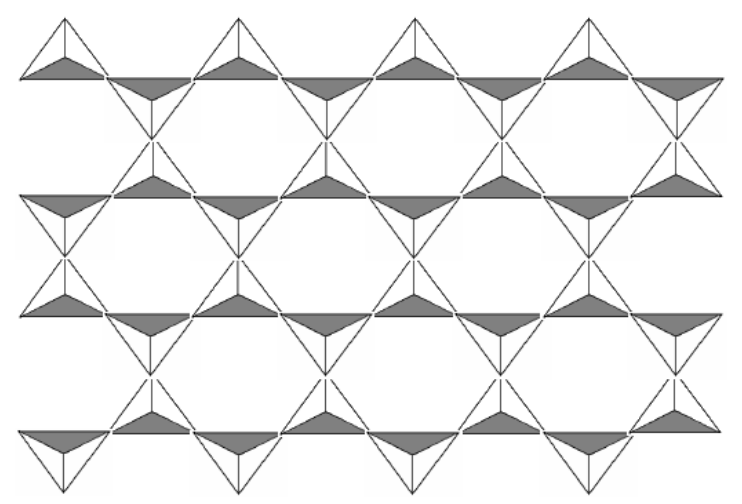

Figura 6 - Estrutura planar das folhas de tetraedros dos filossilicato (adaptado de BERGAYA et al, 2006).

Tectossilicatos: cada tetraedro compartilha os quatro oxigênios gerando estruturas tridimensionais de composição unitária $\left[\mathrm{SiO}_{2}\right]^{0}$ (figura 7), como no quartzo e feldspatos. Um exemplo de tectossilicato é a albita $-\mathrm{NaAlSi}_{3} \mathrm{O}_{8}$.

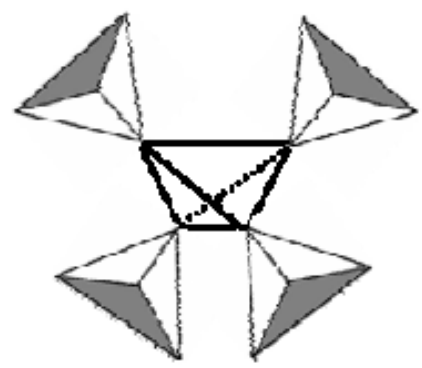

Figura 7 - Estrutura tridimensional dos tectossilicatos (adaptado de BERGAYA et al, 2006).

\subsection{FILOSSILICATOS}

Os filossilicatos ou silicatos em folhas são também conhecidos como argilominerais, porém, nem todo filossilicato é um argilomineral (BROWN, 1984). Os argilominerais são os principais constituintes das argilas, sua estrutura consiste em folhas (portanto o termo silicato em folhas ou filossilicatos), firmemente arranjadas em 
camadas. As lamelas indivíduais são compostas por duas, três ou quatro folhas. As folhas são formadas por tetraedros $\left[\mathrm{SiO}_{4}\right]^{4-}$ chamadas de "T", ou por octaedros $\left[\mathrm{AlO}_{3}(\mathrm{OH})_{3}\right]^{6-}$ chamadas de "O".

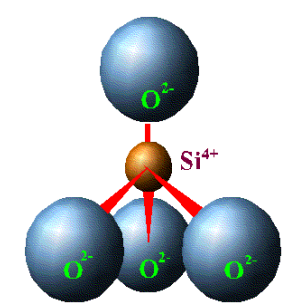

Tetraedro de Sílica

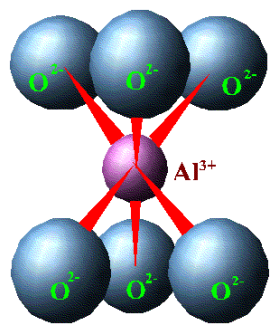

Octaedro de Alumínio

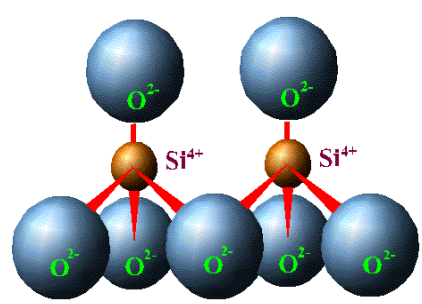

Folha tetraédrica "T"

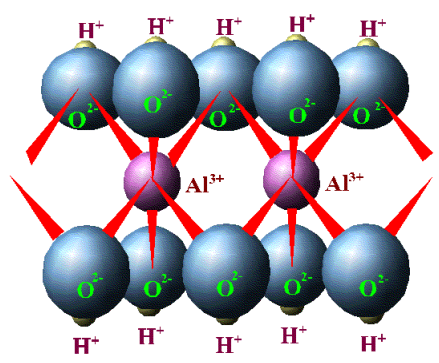

Folha Octaédrica "O"

Figura 8 - Tetraedro de sílica e sua folha "T" e octaedro de alumínio e sua folha "O" (adaptado de JUNIOR, 2006).

Considerando a combinação destas folhas para formação das lamelas e arranjo entre elas, os filossilicatos foram classificados pela AIPEA (Associação Internacional para Estudo de Argilas) em sete grupos (BAILEY, 1980):

Grupo da Caulinita e Serpentina: Filossilicatos com duas folhas, nos quais a relação $[\mathrm{T}: \mathrm{O}]=[1: 1]$ e a carga das folhas por unidade de fórmula é igual a zero. São não expansíveis. Um exemplo de argilomineral deste grupo é a Caulinita $\mathrm{Al}_{2} \mathrm{Si}_{2} \mathrm{O}_{5}(\mathrm{OH})_{4}$, figura 9. 


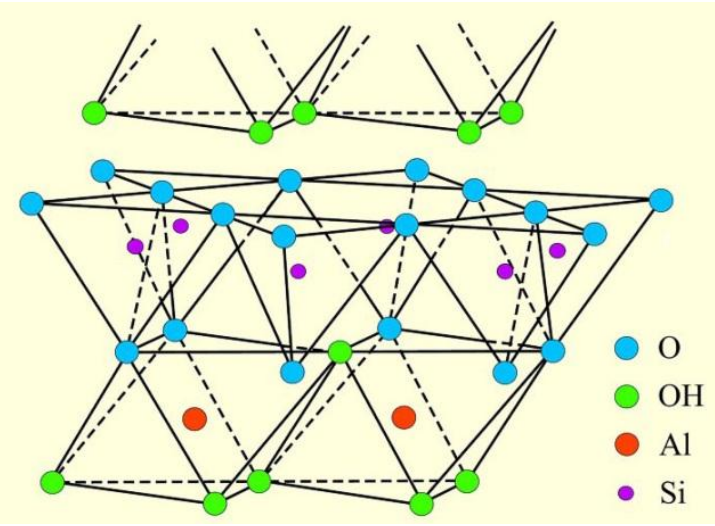

Figura 9 - Estrutura lamelar da caulinita (adaptado de USGS, 2011).

Grupo das Micas: Filossilicatos com três folhas, nos quais a relação [T:O] = [2:1] e a carga das folhas por unidade de fórmula é $\leq 2$. Um exemplo de argilomineral deste grupo é a Illita $\left(\mathrm{K}, \mathrm{H}_{3} \mathrm{O}\right) \mathrm{Al}_{2}(\mathrm{Si}, \mathrm{Al})_{4} \mathrm{O}_{10}(\mathrm{OH})_{2}$, figura 10.

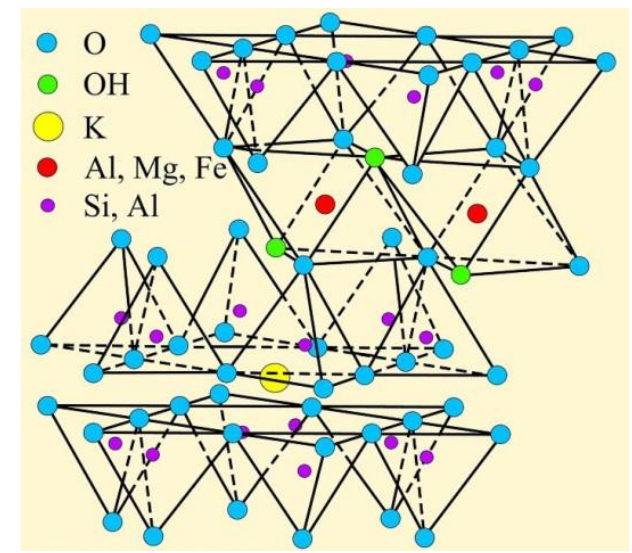

Figura 10 - Estrutura lamelar da illita (adaptado de USGS, 2011).

Grupo das Vermiculitas: Filossilicato expansível com três folhas, nos quais a relação $[\mathrm{T}: \mathrm{O}]=[2: 1]$ e a carga das folhas por unidade de fórmula é de 1,2 à 1,8. Um exemplo de argilomineral deste grupo é a vermiculita magnesiana, a qual contém uma lamela central de íons magnésio entre as camadas 2:1, estes íons se encontram normalmente hidratados $(\mathrm{Mg}, \mathrm{Ca})_{0,4}(\mathrm{Mg}, \mathrm{Fe})_{3}(\mathrm{Si}, \mathrm{Al})_{4} \mathrm{O}_{10}(\mathrm{OH})_{2} .4,5 \mathrm{H}_{2} \mathrm{O}$, figura 11 . 


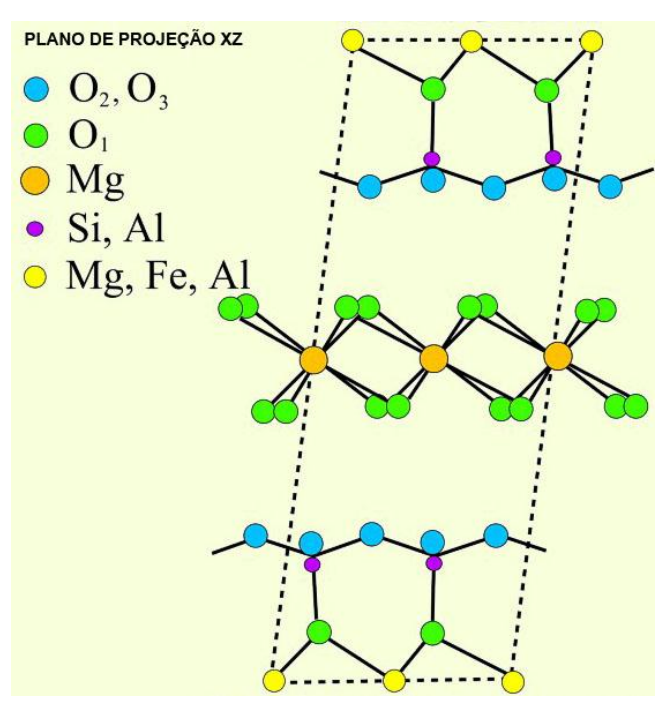

Figura 11 - Estrutura lamelar da vermiculita - Mg (adaptado de USGS, 2011).

Grupo das Esmectitas: Filossilicato fortemente expansível nos quais a relação [T:O] = [2:1] e a carga das folhas por unidade de fórmula é de 0,5 à 1,2. Um exemplo de argilomineral deste grupo é a Montmorilonita, $\mathrm{Na}_{0,66}\left(\mathrm{Al}_{3,34} \mathrm{Mg}_{0,66}\right) \mathrm{Si}_{8} \mathrm{O}_{20}(\mathrm{OH})_{4}$, figura12.

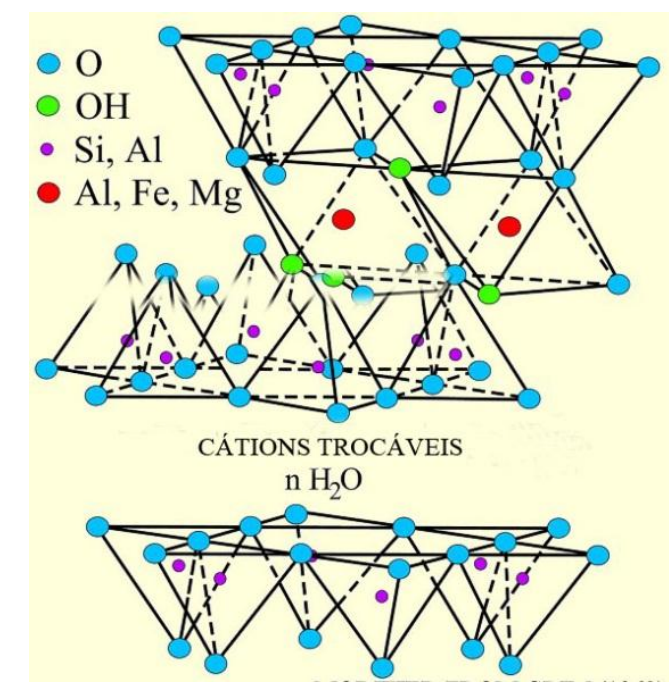

Figura 12 - Estrutura lamelar da montmorilonita (adaptado de USGS, 2011).

Grupo do Talco e Pirofilita: Filossilicatos que não incham em água, nos quais a relação $[\mathrm{T}: \mathrm{O}]=[2: 1]$ e a carga das folhas por unidade de fórmula é zero. Um exemplo de argilomineral deste grupo é o Talco $\mathrm{Mg}_{6}\left[\mathrm{Si}_{8} \mathrm{O}_{20}\right](\mathrm{OH})_{4}$, figura 13 . 


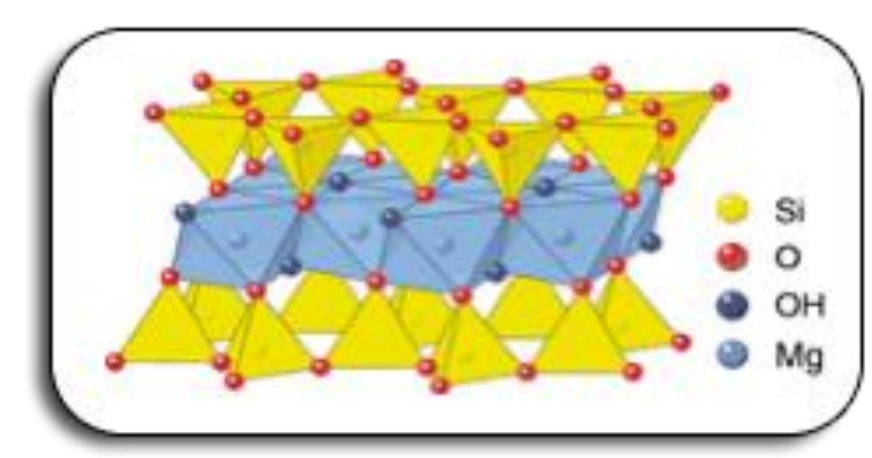

Figura 13 - Estrutura lamelar do talco (adaptado de USGS, 2011).

Grupo das Cloritas: Filossilicatos com quatro folhas, nos quais a relação [T:O:O] = [2:1:1] e a carga das folhas por unidade de fórmula é de 1,1 à 3.3. A camada [T:O] está negativamente carregada, enquanto a folha octaédrica entre as camadas (chamada Brucita), está positivamente carregada (figura 14). Um exemplo de argilomineral deste grupo é a Donbassita $\mathrm{Al}_{4}\left[\mathrm{Si}_{8} \mathrm{O}_{20}\right](\mathrm{OH})_{4} \mathrm{Al}_{4}(\mathrm{OH})_{12}$

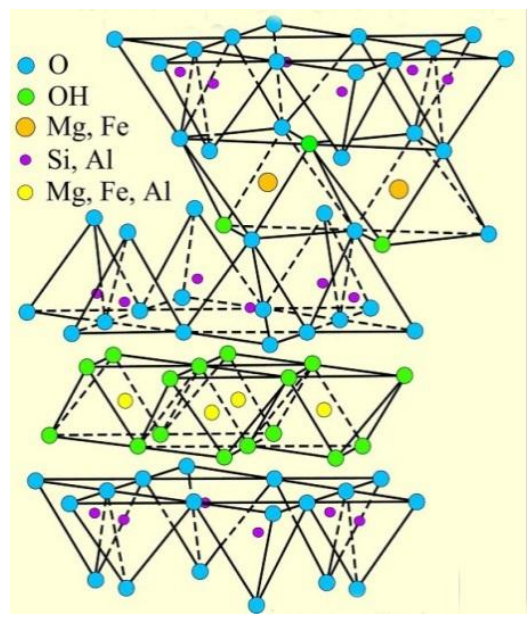

Figura 14 - Estrutura lamelar de uma clorita (adaptado de USGS, 2011).

Grupo da Poligorsquita e Sepiolita: Filossilicatos com as camadas em forma de fibras. As Poligorsquitas apresentam uma maior diversidade estrutural e embora ambos minerais sejam silicatos de magnésio a Poligorsquita possuem menos $\mathrm{Mg} \mathrm{e}$ mais Al que a Sepiolita (MURRAY, 2000). A estrutura de ambos minerais é muito similar (figura 15), possuem folhas tetraédricas apontando na mesma direção, na forma de fitas 2:1 que se estendem na direção do eixo a, além disso, possuem um eixo de amplitude 
b, que corresponde a três cadeias tetraédricas ligadas na sepiolita e duas para poligorsquita. Os canais retângulares formados entre as fitas contêm cátions trocáveis Ca e Mg, além de moléculas de água.
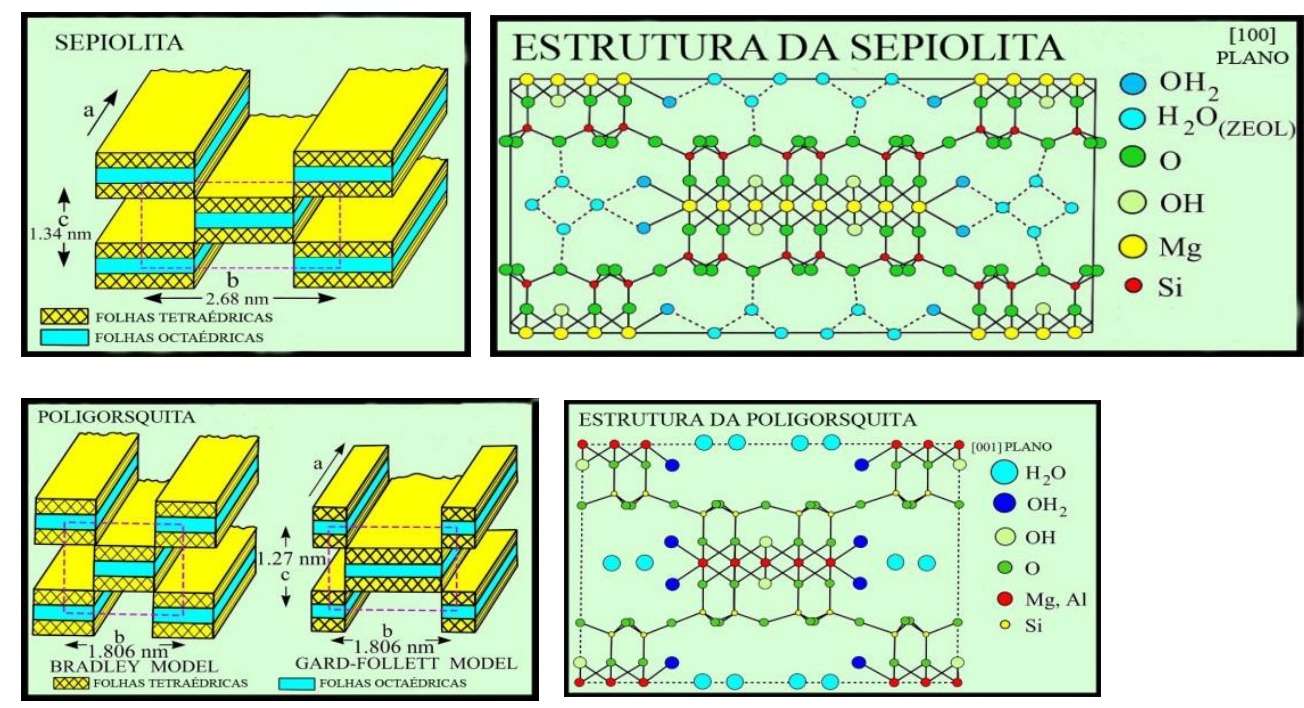

Figura 15 - Estrutura lamelar da sepiolita e da poligorsquita (adaptado de USGS, 2011).

\subsection{BENTONITAS}

O termo bentonita foi pela primeira vez aplicado a um tipo de argila plástica e coloidal de uma rocha descoberta em Fort Benton, Wyoming - EUA. Embora, originalmente, o termo bentonita se referisse à rocha argilosa descoberta, atualmente designa argila constituída principalmente do argilomineral montmorilonita. Este argilomineral faz parte do grupo das esmectitas. O termo bentonita também é usado para designar um produto com alto teor de esmectita. Originam-se mais frequentemente da desvitrificação e alteração química de cinzas vulcânicas e podem apresentar outros componentes, tais como: outros argilominerais (caolinita, ilita), feldspatos, anfibólios, cristobalita e quartzo (DNPM, 2009). Podem apresentar cores variadas, tais como: branco, cinza, amarelo, marrom, verde e azul, pode ser cálcica, sódica ou policatiônica, e apresenta uma característica física muito particular: pode expandir várias vezes o seu 
volume, quando em contato com a água, formando géis tixotrópicos (BALTAR; LUZ, 2004).

Na lamela (figura 16) podem ocorrer substituições de íons por outros de diferente número de oxidação. Nos tetraedros, por exemplo, o íon $\mathrm{Al}^{3+}$ pode aparecer substituindo o $\mathrm{Si}^{4+}$. No entanto nos octaedros, por exemplo, os íons $\mathrm{Mg}^{2+}, \mathrm{Fe}^{3+}$ e/ou $\mathrm{Fe}^{2+}$ podem substituir o $\mathrm{Al}^{3+}$ (LUZ; OLIVEIRA, 2005). Esse tipo de substituição provoca um desbalanceamento elétrico que é compensado por cátions, como $\mathrm{Na}^{+} \mathrm{e} \mathrm{Ca}^{2+}$, que se posicionam entre as lamelas e são intercambiáveis, dando origem às denominações capacidade de troca de cátion (CTC) sódica e cálcica das bentonitas. Algumas bentonitas, menos comuns, podem apresentar íons $\mathrm{H}^{+}, \mathrm{K}^{+}$e $\mathrm{Mg}^{2+}$ como cátions de compensação. O desbalanceamento de carga na superfície de uma esmectita pode variar de 0,5 a 1,2 por unidade de célula. Entendendo melhor o significado do termo capacidade de troca de cátion (CTC) e da carga de superfície gerada, considera-se a fórmula da meia cela unitária da montmorilonita.
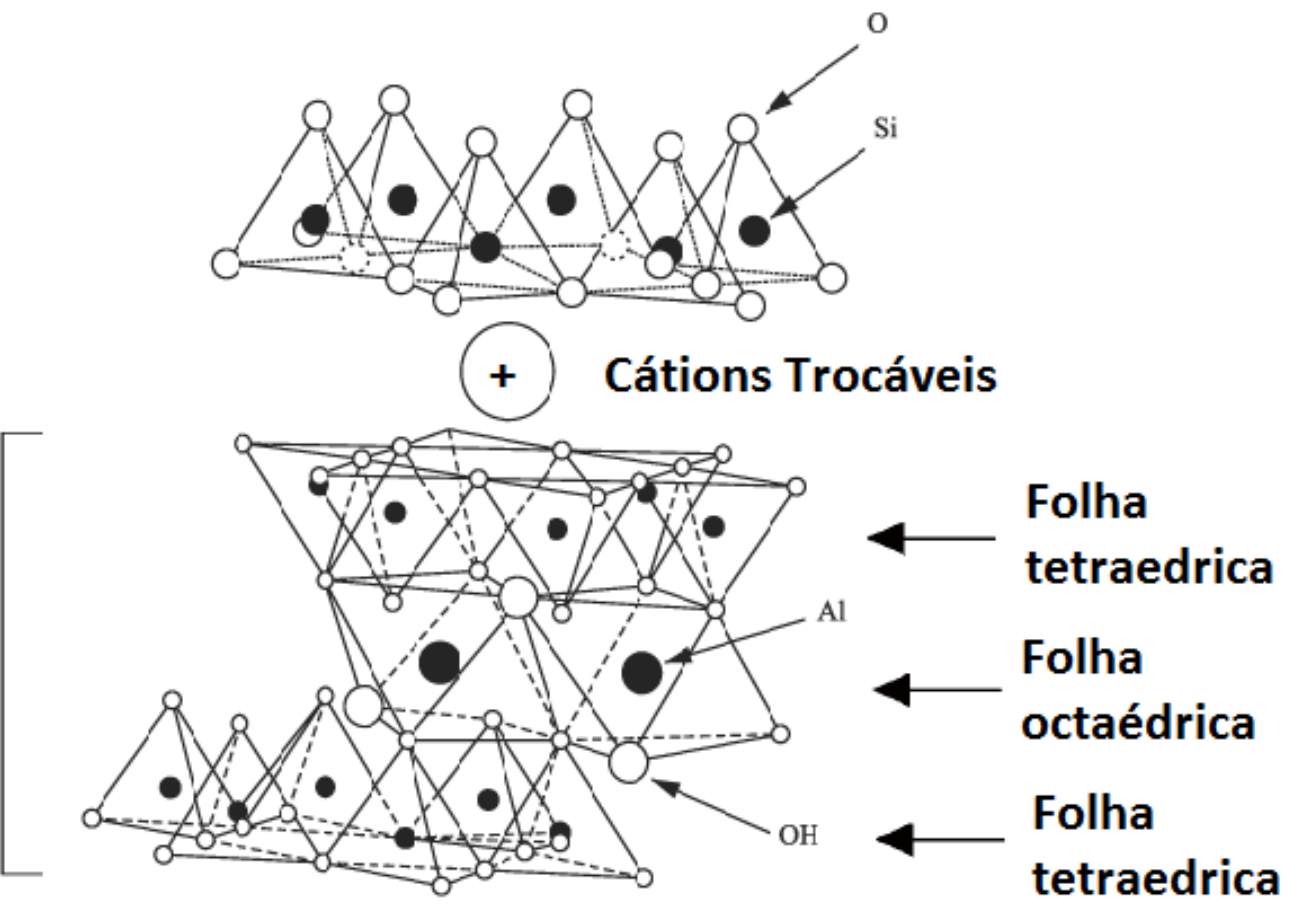

Figura 16 - Representação esquemática da estrutura das lamelas de uma esmectita (adaptado de COELHO; SANTOS, 2007). 


$$
\left[\left(\mathrm{Al}_{(2-y)} \mathrm{Mg}_{y}\right)\left(\mathrm{Si}_{(4-x)} \mathrm{Al}_{x}\right) \mathrm{O}_{10}(\mathrm{OH})_{2}\right]\left[M_{(x+y)}\right] n \mathrm{H}_{2} \mathrm{O} \quad ;
$$

Onde:

Y é a quantidade de átomos de alumínio substituíveis na folha octaédrica;

$X$ é a quantidade de átomos de silício substituíveis na folha tetraédrica;

$M_{(x+y)}$ são os cátions monovalentes presentes na estrutura do argilomineral para compensar a carga resultante após a substituição de um átomo de alumínio e/ou silício ter ocorrido nas folhas octaédrica e tetraédrica, respectivamente.

Considerando que a quantidade total da capacidade de troca de cátion (CTC) seja a soma de $x+y$ e compreenda um intervalo $0,5 \leq(x+y) \leq 1,2$. Este intervalo representa a quantidade mínima e máxima expressa em equivalentes de cátion trocáveis em um mol do argilomineral (SOUZA SANTOS, 1992). Respeitando a estequiometria, convencionou-se expressar a CTC dos argilominerais, na forma de miliequivalentes por $100 \mathrm{~g}$ de argila (meq/100 $\mathrm{g}$ de argila).

Os principais depósitos mundiais de bentonita estão localizados nos Estados Unidos da América, com reserva estimada em 12 milhões de toneladas distribuídas, principalmente, nos estados de Wyoming, Montana e South Dakota. Os Estados Unidos são um dos únicos produtores mundiais da bentonita naturalmente sódica. No Brasil, as reservas são estimadas em 39 milhões de toneladas (ARANHA et al., 2002), concentrando-se nos estados da Paraíba (62\%), São Paulo (28\%), Bahia, Minas Gerais e Paraná (10\%). O estado da Paraíba é responsável por $96 \%$ da bentonita beneficiada, quase toda a produção de bentonita é oriunda do município de Boa Vista, enquanto que o beneficiamento é feito nos municípios de Soledade, Boa Vista, Campina Grande e Pocinhos.

Para uso industrial, existem dois tipos de argilas bentoníticas: as que não incham em presença de água, que têm o cálcio como cátion interlamelar predominante ou não possuem nenhum cátion interlamelar preponderante (bentonitas policatiônicas), e as que incham em presença de água, nas quais o sódio é o cátion interlamelar predominante. As bentonitas sódicas adsorvem água continuamente inchando e aumentando 
de volume até a completa esfoliação de suas lamelas cristalinas em água, proporcionando à bentonita sódica os seus usos tecnológicos característicos e exclusivos. As bentonitas cálcicas não se esfoliam em suspensão aquosa: o inchamento de suas partículas é pequeno e elas precipitam rapidamente. As bentonitas produzidas no Brasil são policatiônicas e o país não tem reservas conhecidas de bentonitas sódicas. Toda bentonita sódica disponível no país ou é importada ou é produzida a partir da bentonita cálcica, por adição de carbonato de sódio em processos industriais.

O beneficiamento das bentonitas da Paraíba (LUZ, 2005) consta de: desintegração, adição de 2,5 a $3 \%$ em peso de barrilha, homogeneização, laminação ou extrusão, cura (2 a 10 dias), secagem, moagem, classificação pneumática e ensacamento (figura 17). Não existe, atualmente, uma uniformidade no processamento das bentonitas da Paraíba. Algumas empresas fazem a adição da barrilha a seco, outras a úmido. A secagem e o tempo de ativação variam de empresa para empresa; algumas secam ao sol outras usam secador rotativo.

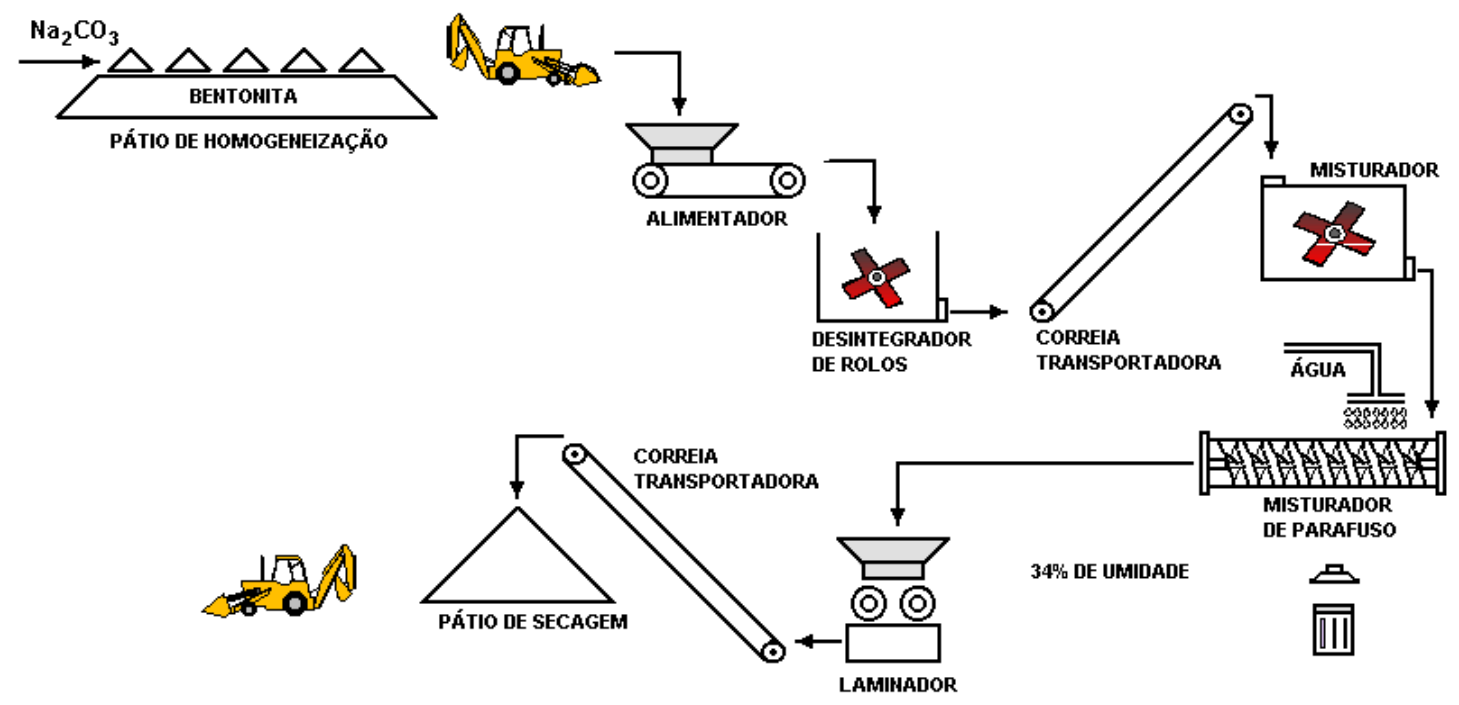

Figura 17 - Fluxograma de processamento de bentonita da Paraíba (adaptado de LUZ, 2005). 
Entre as principais aplicações e usos industriais das bentonitas destaca-se: (a) componente de fluidos utilizados para perfuração de poços de petróleo (b) aglomerante de areias de moldagem usadas em fundição; (c) pelotização de minério de ferro; (d) descoramento de óleos e clarificação de bebidas; (e) impermeabilizante de solos; (f) absorvente sanitário para animais de estimação; (g) carga mineral, em produtos farmacêuticos, rações animais, produtos cosméticos e outros; (h) agente plastificante para produtos cerâmicos, (i) composição de cimento, entre outros (TEIXEIRA-NETO, 2009).

\subsection{SAIS QUATERNÁRIOS DE AMÔNIO (SQA)}

Sais quaternários de amônio são produtos da reação de substituição nucleofílica de um haleto de alquila com uma amina terciária, ver um exemplo na figura 18.

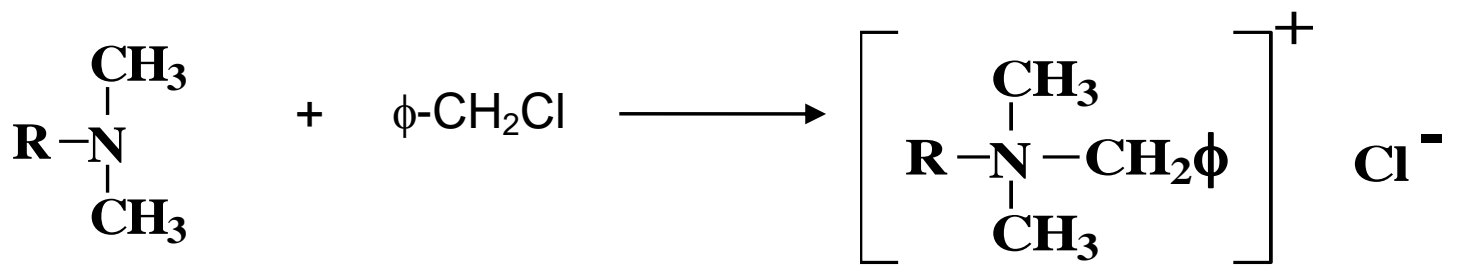

Figura 18. - Reação de uma alquil dimetil amina com cloreto de benzila gerando um cloreto de alquil benzil dimetil amônio.

Sais quaternários de amônio possuem quatro átomos de carbono ligados diretamente a um átomo de nitrogênio, através de ligações covalentes, enquanto que o ânion permanece ligado ao nitrogênio por ligação iônica (eletrostática). Uma fórmula geral para um sal quaternário de amônio é representada na figura 19 (SOLOMONS; FRUHLE, 2001). 


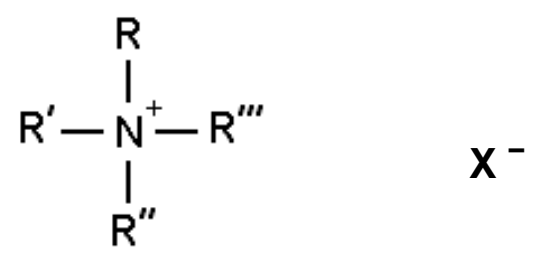

Figura 19 - Fórmula geral para um sal quaternário de amônio.

Onde R, R', R" e R"' são os grupos alquílicos podendo ser iguais ou diferentes entre si. A porção cátion positivamente carregada da molécula é formada pelo átomo de nitrogênio ligado aos grupos alquílicos, sendo esta a parte funcional da molécula. A porção ânion corresponde ao radical $X^{-}$(figura acima), o qual está ligado através de uma ligação iônica (eletrostática) ao átomo de nitrogênio, sendo $X$, usualmente brometo $\left(\mathrm{Br}^{-}\right)$ou cloreto $\left(\mathrm{Cl}^{-}\right)$, formando o sal.

Sais quaternários de amônio são amplamente usados como agentes antissépticos, desinfetantes, detergentes e preservantes. PALMER e MALONEY (1955), WALKER e EVANS (1978) avaliaram o efeito algicida de compostos quaternários de amônio com diferentes grupos alquílicos e concluíram que o cloreto de dodecil dimetil benzil amônio apresenta a maior efetividade contra algas verdes, sendo um dos sais quaternários de amônio mais utilizados como algicida (BEVERIDGE, 1998).

Muitos desinfetantes, utilizados em hospitais para limpeza de instrumentos cirúrgicos e para limpeza de superfícies, contem cloretos de benzalcônio (CHAPMAN, 2003 e ROSSI, 2008). Como preservativo e antisséptico eles são encontrados em cosméticos, detergentes, xampus, óleos para pele e até soluções para limpeza de lentes de contato (PUROHIT et al., 2000). 


\subsection{ARGILAS ORGANOFÍLICAS}

As argilas esmectitas tem sua morfologia característica em forma de camadas (figura 20), com espessura por volta de $0,93 \mathrm{~nm}$ e diâmetro de 200 à $500 \mathrm{~nm}$, sua área superficial maior que $750 \mathrm{~m}^{2} / \mathrm{g}$, e capacidade de troca de cátions de 80 à $150 \mathrm{meq} / 100 \mathrm{~g}$ (CARASTAN, 2007). Os grupos $\mathrm{Si}-\mathrm{OH}$ presentes nas bordas das lamelas podem atuar como ácidos de Bronsted, originando uma leve densidade de carga positiva. Muitas propriedades químicas e físicas são determinadas pelas propriedades de superfície. Os nanomateriais podem ter propriedades diferenciadas em relação ao mesmo material quando seu tamanho está expresso em micros (TEIXEIRA-NETO, 2009).

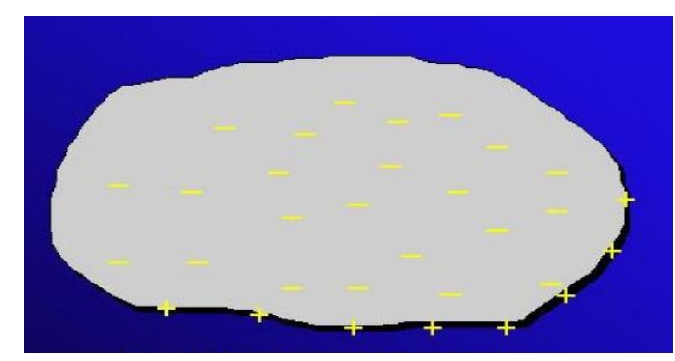

Figura 20 - Representação de uma folha de esmectita (adaptada de BOTELHO, 2006).

As camadas do argilomineral em escala nanométrica possuem uma grande área superficial para uma dada massa. O empilhamento entre camadas é regido por forças polares relativamente fracas (força de Van der Walls). Entre as camadas existem lacunas denominadas galerias ou espaços interlamelares (FONSECA; AIROLDI, 2003).

As galerias entre as camadas são ocupadas por cátions trocáveis. Os cátions trocáveis podem ser orgânicos ou inorgânicos. Adicionalmente, a hidratação dos cátions interlamelares causa o acúmulo de moléculas de água no espaço interlamelar das argilas e seu conseqüente inchamento ou expansão, aumentando as distâncias interlamelares ou até mesmo chegando a separá-las totalmente, deixando-as livres quando a distancia interplanar fica superior a $40 \AA$, dessa forma, as superfícies das lamelas hidratadas tornam a argila hidrofílica. $O$ termo argilas catiônicas é usado para 
designar tanto as argilas sódicas como as cálcicas e policatiônicas (COELHO; SANTOS, 2007).

As argilas organofílicas são obtidas pela troca iônica dos cátions interlamelares de argilas catiônicas por cátions orgânicos (KOZAC; DOMKA; SKRZYPCZAK, 2002), principalmente sais quaternários de amônio (figura 21). Dessa forma, a superfície das lamelas individuais de argila torna-se hidrofóbica ou organofílica.

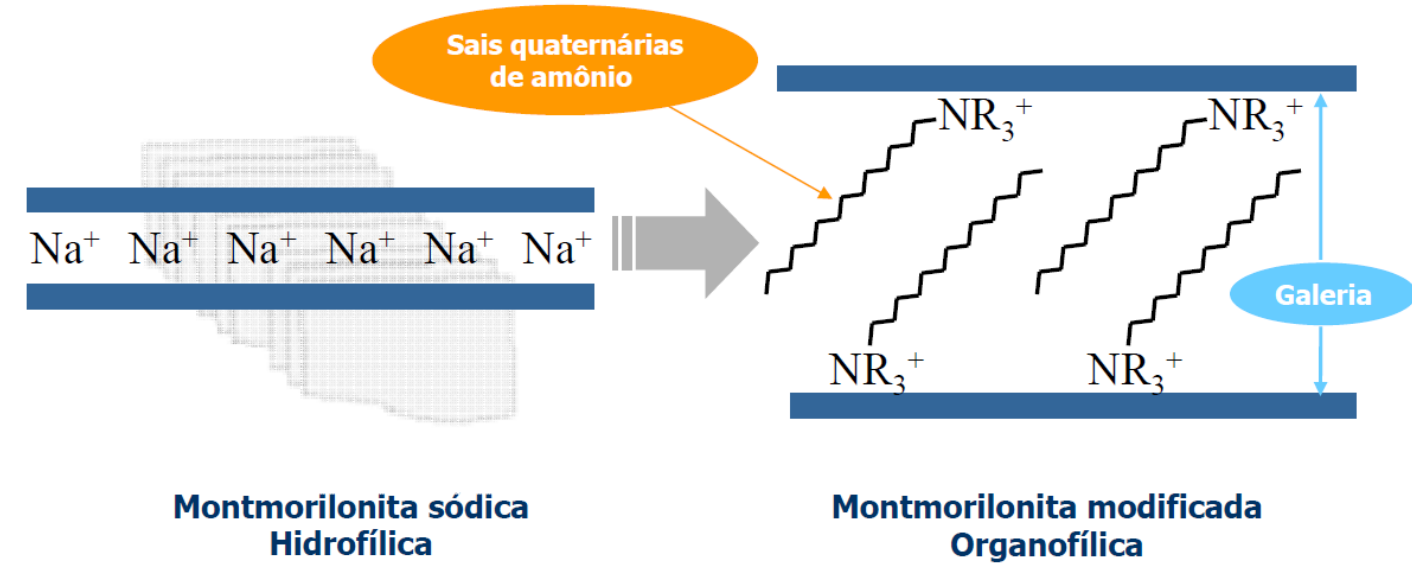

Figura 21 - Mecanismo de organofilização de uma montmorilonita sódica (adaptada de LEITE, 2008).

As esmectitas hidrofílicas incham somente em meios polares, e as organofílicas incham em meios não polares ou orgânicos. Em geral utilizam-se argilas com cátions trocáveis tipo $\mathrm{Na}^{+}$, que por ser monovalente e possuir uma alta capacidade de hidratação são mais facilmente trocável (THENG, 1974). Existem inúmeros sais quaternários de amônio para preparação de argilas organofílicas e a quantidade ligada à superfície das camadas da argila é limitada pela capacidade de troca de cátions.

Dependendo da carga da camada (CTC) do argilomineral e do comprimento da cadeia alquilica do sal quaternário de amônio, diferentes arranjos entre as camadas podem se formar. A formação de monocamadas, bicamadas e camadas pseudotrimolecular pelos compostos quaternários de amônio (CQA), nos espaços interlamelares das montmorilonitas foram estudadas por Lagaly (1976). A substituição do cátion $\mathrm{Na}^{+}$pelo cátion quaternário de amônio altera o valor da distância interplanar basal da montmorilonita, conforme ilustra a figura 22. 


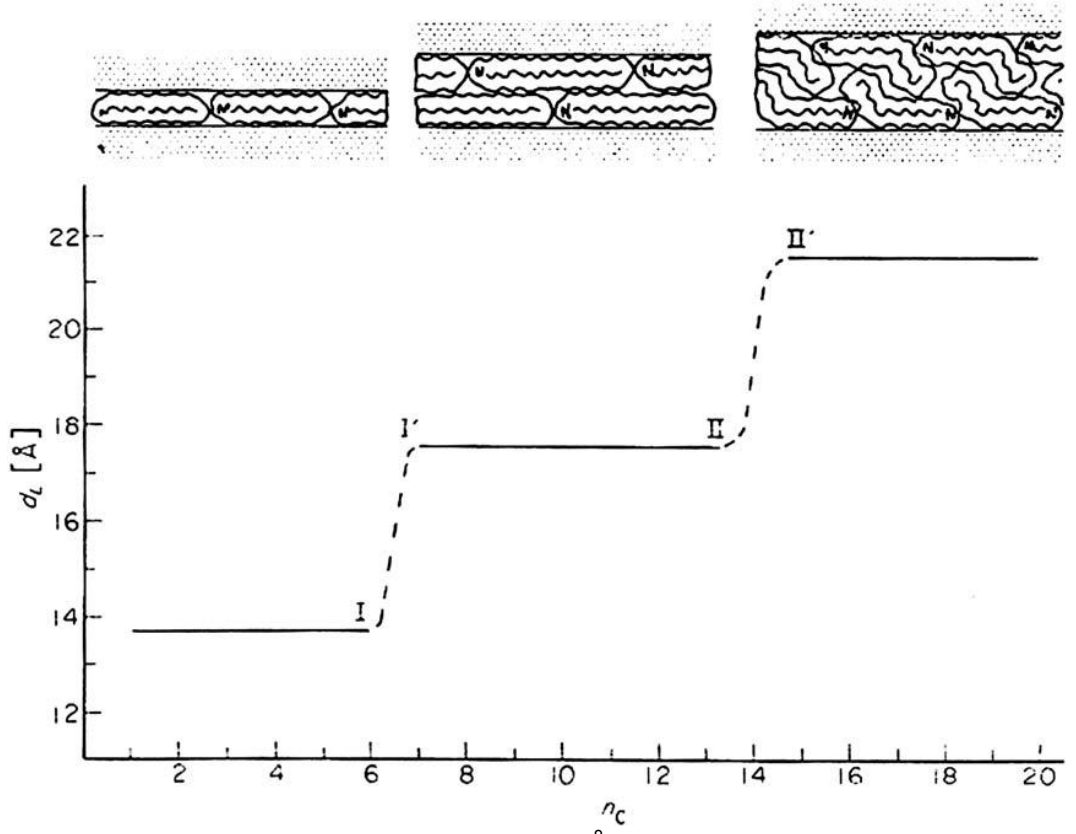

Figura 22 - Variação do espaçamento basal $\left(d_{L}\left[\AA \AA^{c}\right]\right)$ de montmorilonitas modificadas com sais quaternários de amônio com diferentes comprimentos da cadeia alquilica(nc) (adaptada de PAIVA, 2008).

Os protocolos de organofilização descritos na literatura científica (PEREIRA; VIEIRA; MELO, 2007) geralmente envolvem a preparação de suspensões aquosas de argila, com concentrações entre 3 e 10\% em massa, e a posterior adição de soluções de tensoativos quaternários de amônio à suspensão. A argila organofílica é assim obtida na forma de uma torta úmida, que é separada por filtração, seca em estufa e moída.

Devido à afinidade que possuem por compostos orgânicos, as argilas organofílicas estão sendo largamente estudadas na adsorção e retenção de resíduos perigosos industriais e contaminantes sólidos (VIEIRA et al, 2002), podem ser usadas no tratamento de águas contaminadas, sendo ainda indicado para revestimento de reservatórios de disposição de resíduos, tratamento de efluentes, controle de derramamentos de óleos ou petróleo, componente tixotrópico de fluidos de perfuração de poços de petróleo à base de óleo (VALENZUELA-DIAZ, SANTOS, 1992 a, b), nas industrias de fundição de metais, lubrificantes, tintas, adesivos, cosméticos e nanocomposito na industria automobilística e de embalagens, uma das mais importantes áreas da nanotecnologia (PAIVA et al, 2008 e PATEL et al, 2006). 


\subsection{ESTRUTURA CELULAR}

As células são consideradas as unidades básicas de qualquer organismo, desde os microorganismos constituídos por uma única célula às formas de vida com tecidos especializados e órgãos complexos. O avanço da microscopia eletrônica na década de 1940 expôs muito mais a estrutura celular interna do que era possível com os microscópios óticos. Uma descoberta particularmente importante em termos de taxonomia foi que as células microbianas podem ser divididas em duas categorias com base em como a substância nuclear se apresente dentro da célula: células eucarióticas têm um núcleo separado do citoplasma por uma membrana nuclear, enquanto as células procarióticas apresentam material nuclear sem membrana (figura 23). As bactérias têm uma estrutura celular procariótica e as algas, fungos, protozoários e células vegetais e animais têm células eucarióticas (CARVALHO; RECCO-PIMENTEL, 2007).

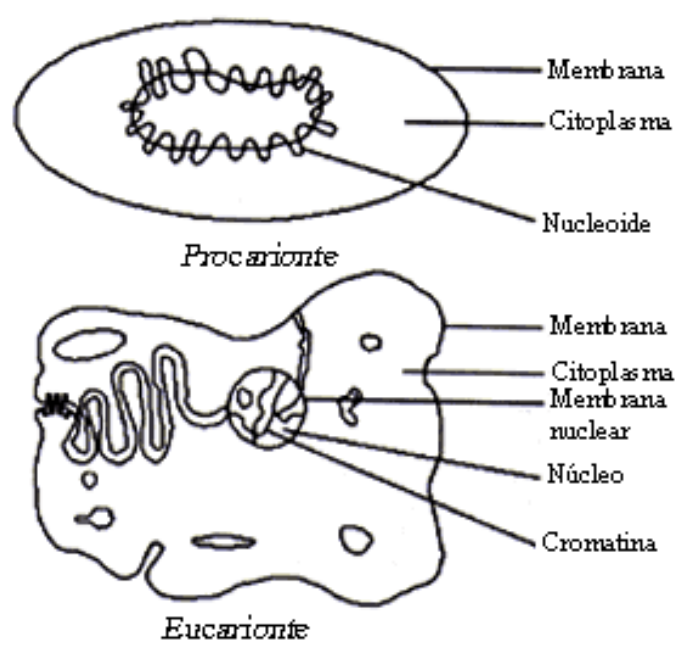

Figura 23 - Estrutura celular procarionte e eucarionte (adaptado de CARVALHO, 2007).

Toda a célula seja procarionte ou eucarionte, apresenta uma diversidade de estruturas funcionando juntas, sendo algumas comuns a todas as células e outras estruturas estando presentes somente em certas espécies ou sob certas condições 
ambientais. Algumas destas estruturas (figura 24) são encontradas internamente (ribossomos, retículo endoplasmático, complexo de golgi, mitocôndria, cloroplastos, núcleo e nucléolo) e outras externamente (flagelos, pêlos, glicocálice, parede celular e membrana citoplasmática).

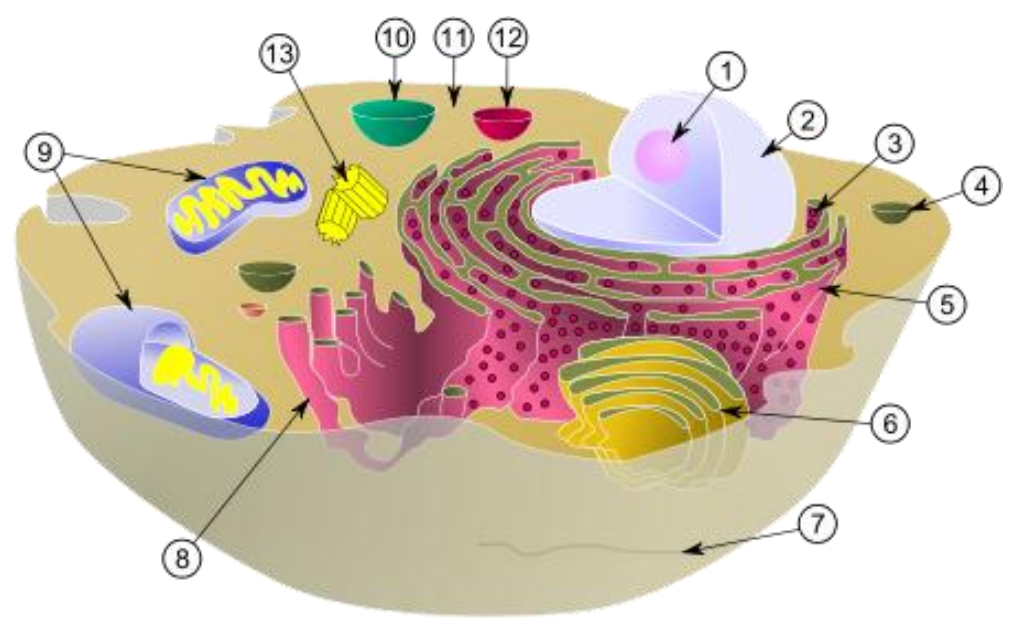

Figura 24 - Representação de uma célula eucarionte: 1.Nucléolo; 2.Núcleo; 3.Ribossomas; 4.Vesículas; 5.Retículo endoplasmático rugoso (RER); 6.Complexo de Golgi; 7.Microtúbulos; 8.Retículo endoplasmático liso (REL); 9.Mitocôndrias; 10.Vacúolo; 11.Citoplasma; 12.Lisossomas; 13. Centríolos (adaptado de CARVALHO, 2007).

A membrana citoplasmática possui espessura entre 6 a $9 \mathrm{~nm}$. Estudos com membranas plasmáticas isoladas revelam que seus componentes mais abundantes são fosfolipídios, colesterol e proteínas. É por isso que se costuma dizer que as membranas plasmáticas têm constituição lipoprotéica. Uma vez identificados os fosfolipídios e as proteínas como os principais componentes moleculares da membrana, os cientistas passaram a investigar como estas substâncias estavam organizadas. A disposição das moléculas na membrana plasmática foi elucidada recentemente, sendo que os lipídios formam uma camada dupla e contínua, no meio da qual se encaixam moléculas de proteína. A dupla camada de fosfolipídios é fluida, de consistência oleosa, e as proteínas mudam de posição continuamente, como se fossem peças de um mosaico 
(figura 25). Esse modelo foi sugerido por dois pesquisadores, Singer e Nicholson, e recebeu o nome de Modelo Mosaico Fluido (CARVALHO, RECCO-PIMENTEL, 2007).

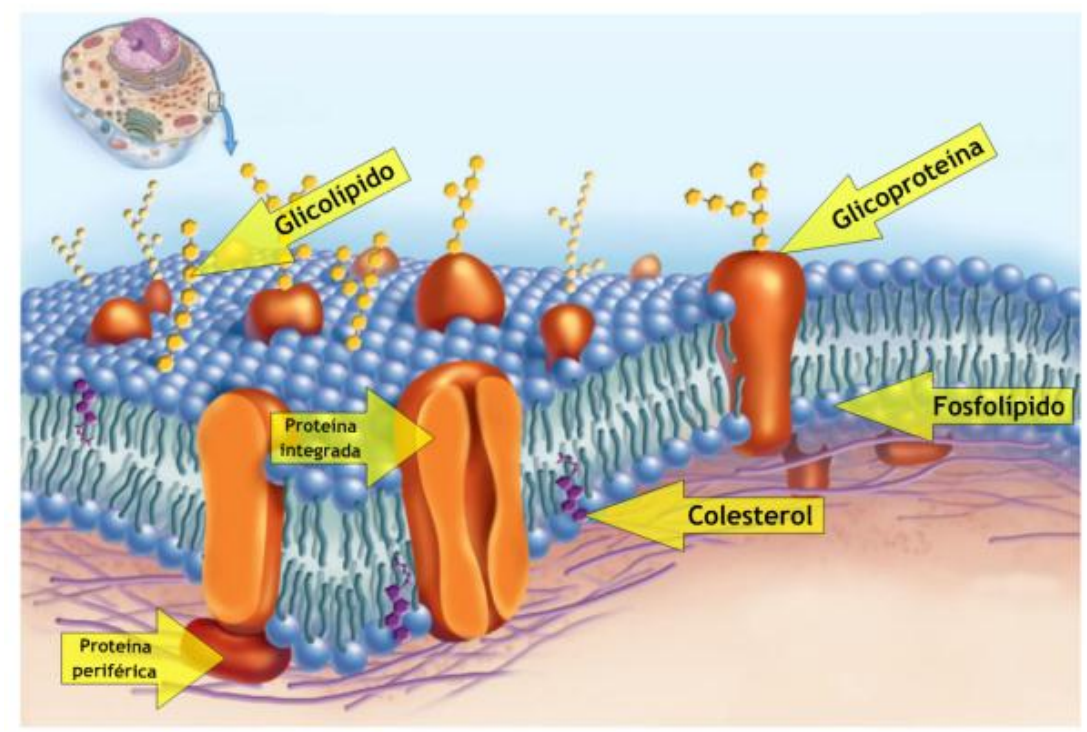

Figura 25 - Representação do modelo mosaico fluido da membrana citoplasmática destacando seus principais componentes: glicolipídeo, glicoproteina, fosfolipídeo, colesterol, proteína integrada e proteína periférica (adaptado de CARVALHO, 2007).

Os fosfolipídios (figura 26) têm a função de manter a estrutura da membrana e as proteínas têm diversas funções. A membrana plasmática de um eucariótico contém quantidades particularmente grandes de colesterol. As moléculas de colesterol aumentam as propriedades de barreira da bicamada lipídica e devido a seus rígidos anéis planos de esteróides diminuem a mobilidade e tornam a bicamada lipídica menos fluida. 


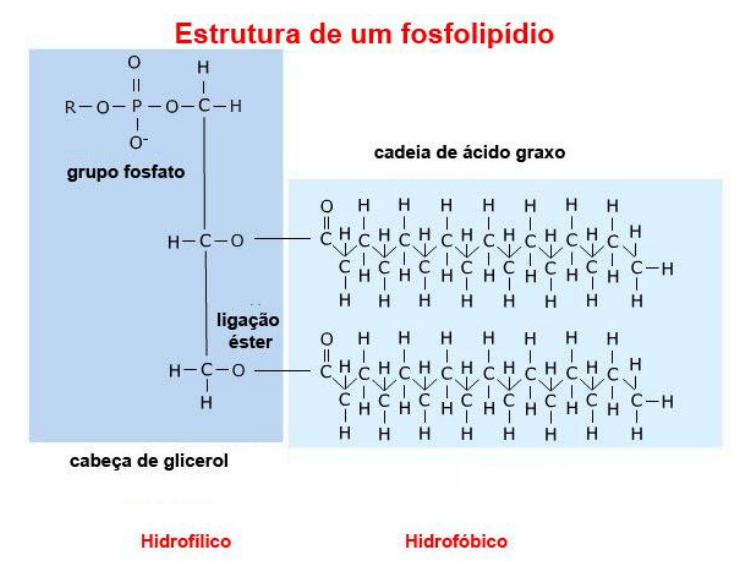

Figura 26 - Estrutura de um fosfolipídio (adaptado de CARVALHO, 2007).

As proteínas da membrana plasmática podem ser integradas ou intrínsecas, quando penetram na bicamada lipídica e periférica ou extrínseca quando se encontram ligadas à superfície da membrana. Os glicídios membranares situam-se na parte externa da membrana citoplasmática podendo ligar-se a proteínas (glicoproteína) ou a lipídeos (glicolípideo) apresentando um papel importante no reconhecimento de substâncias. As proteínas exercem grandes variedades de funções, e podem ser classificadas como (figura 27):

Proteínas de transporte: facilitam o transporte de substâncias entre células;

Proteínas de ação enzimática: uma ou mais proteínas podem atuar isoladamente como enzima na membrana ou em conjunto, como se fossem parte de uma "linha de montagem" de uma determinada via metabólica;

Proteínas receptoras de membrana: podem desempenhar papel na difusão facilitada, formando um canal por onde passam algumas substâncias, ou no transporte ativo, em que existe gasto de energia fornecida pela substância ATP;

Proteínas de reconhecimento: determinadas glicoproteínas atuam na membrana como um verdadeiro "selo marcador", sendo identificadas especificamente por outras células;

Proteínas de adesão: em células adjacentes, as proteínas da membrana podem aderir umas às outras; 
Proteínas de ancoragem: servem como ponto de ancoragem para 0 citoesqueleto.
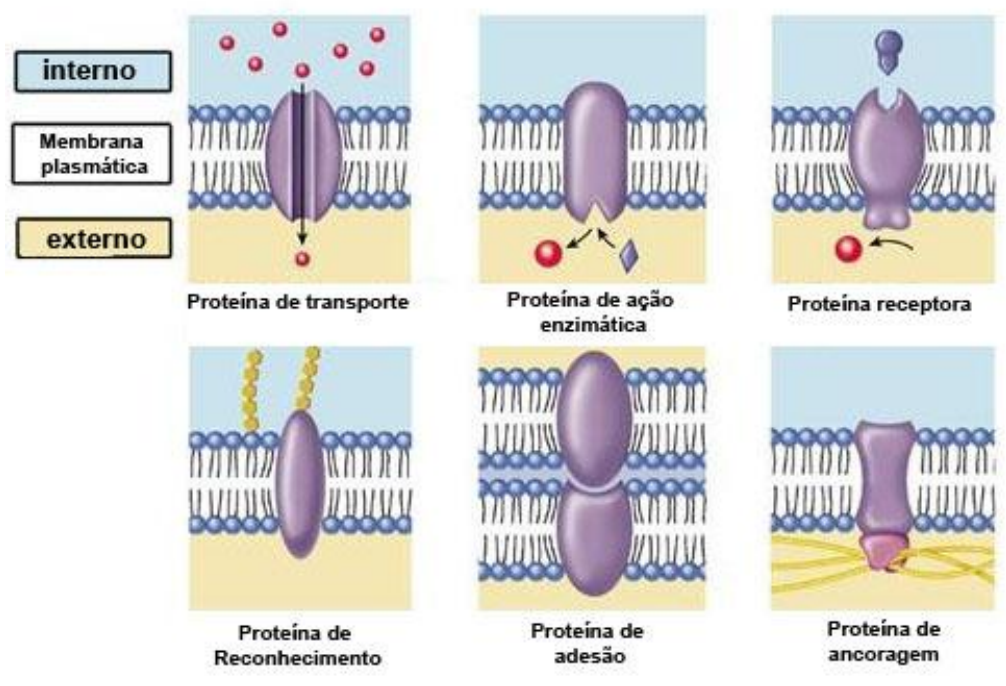

Figura 27 - Funções das proteínas na membrana plasmática (adaptado de BIOLOGY, 2011).

\subsection{TRANSPORTE PELA MEMBRANA CITOPLASMÁTICA}

A capacidade de uma membrana de ser atravessada por algumas substâncias e não por outras define sua permeabilidade. Em uma solução encontra-se o solvente (meio líquido dispersante) e o soluto (partícula dissolvida). Classificam-se as membranas, de acordo com a permeabilidade, em 4 tipos (BOLSOVER et al., 2005):

a) Permeável: permite a passagem do solvente e do soluto;

b) Impermeável: não permite a passagem do solvente nem do soluto;

c) Semipermeável: permite a passagem do solvente, mas não do soluto;

d) Seletivamente permeável: permite a passagem do solvente e de alguns tipos de soluto.

Nessa última classificação se enquadra a membrana plasmática. A passagem aleatória de partículas sempre ocorre de um local de maior concentração para outro de 
concentração menor (a favor do gradiente de concentração). Isso se dá até que a distribuição das partículas seja uniforme. A partir do momento em que o equilíbrio for atingido, as trocas de substâncias entre dois meios tornam-se proporcionais.

A passagem de substâncias através das membranas celulares envolve vários mecanismos, entre os quais podemos citar:

- Transporte passivo: Osmose, Difusão simples, Difusão facilitada;

- Transporte ativo: Bomba de sódio e potássio;

\section{Transporte Passivo}

Ocorre sempre a favor do gradiente, no sentido de igualar as concentrações nas duas faces da membrana, não envolve gasto de energia.

\section{Osmose}

A água se movimenta livremente através da membrana, sempre do local de menor concentração de soluto para o de maior concentração. A pressão com a qual a água é forçada a atravessar a membrana é conhecida por pressão osmótica.

A osmose não é influenciada pela natureza do soluto, mas pelo número de partículas. Quando duas soluções contêm a mesma quantidade de partículas por unidade de volume, mesmo que não sejam do mesmo tipo, exercem a mesma pressão osmótica e são isotônicas. Caso sejam separadas por uma membrana, haverá fluxo de água nos dois sentidos de modo proporcional.

Quando se comparam soluções de concentrações diferentes, a que possui mais soluto e, portanto, maior pressão osmótica é chamada hipertônica, e a de menor concentração de soluto, e menor pressão osmótica é hipotônica. Separadas por uma membrana, há maior fluxo de água da solução hipotônica para a hipertônica, até que as duas soluções se tornem isotônicas. A osmose pode provocar alterações de volume celular. 


\section{Difusão Simples}

Consiste na passagem das moléculas do soluto, do local de maior para o local de menor concentração, até estabelecer um equilíbrio. É um processo lento, exceto quando o gradiente de concentração for muito elevado ou as distâncias percorridas forem curtas. A passagem de substâncias, através da membrana, se dá em resposta ao gradiente de concentração.

\section{Difusão Facilitada}

Certas substâncias entram na célula a favor do gradiente de concentração e sem gasto energético, mas com uma velocidade maior do que a permitida pela difusão simples. Isto ocorre, por exemplo, com a glicose, com alguns aminoácidos e certas vitaminas. A velocidade da difusão facilitada não é proporcional à concentração da substância. Aumentando-se a concentração, atinge-se um ponto de saturação, a partir do qual a entrada obedece à difusão simples. Isto sugere a existência de uma molécula transportadora chamada permease na membrana. Quando todas as permeases estão sendo utilizadas, a velocidade não pode aumentar. Como alguns solutos diferentes podem competir pela mesma permease, a presença de um dificulta a passagem do outro.

\section{Transporte ativo}

Neste processo, as substâncias são transportadas com gasto de energia, podendo ocorrer do local de menor para o de maior concentração (contra o gradiente de concentração).

\section{Bomba de Sódio e Potássio}

O gradiente pode ser químico ou elétrico. O transporte ativo age como uma "porta giratória". A molécula a ser transportada liga-se à molécula transportadora 
(proteína da membrana) como uma enzima se liga ao substrato. A molécula transportadora gira e libera a molécula carregada no outro lado da membrana. Em seguida gira novamente, voltando à posição inicial. A bomba de sódio e potássio liga-se em um íon $\mathrm{Na}^{+}$na face interna da membrana e o libera na face externa (figura 28). Ali, se liga a um íon $\mathrm{K}^{+}$e o libera na face interna. A energia para o transporte ativo vem da hidrólise do ATP.

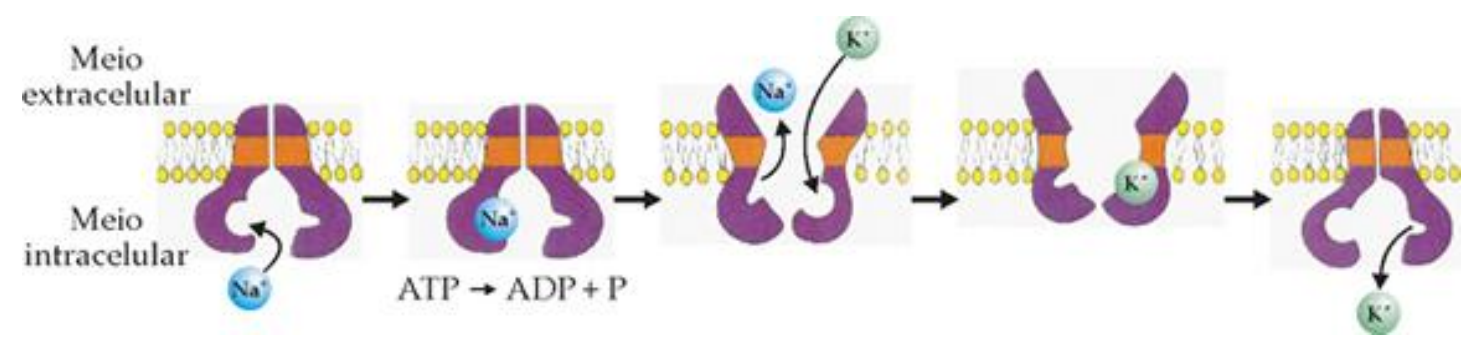

Figura 28 - Funcionamento de bomba de sódio e potássio

(adaptado de BIOLOGY, 2011).

\subsection{AGENTES MICROBIANOS OU BIOCIDAS}

Agentes microbianos ou biocidas são substâncias químicas utilizadas para matar ou inibir o crescimento de microorganismos (no caso de algas usam-se os termos algicida e algiostático respectivamente). $\mathrm{Na}$ literatura o termo algicida é empregado também para designar substâncias que inibem o crescimento de algas. Os biocidas podem ser classificados de acordo com seu mecanismo de ação como (PAULUS, 2005):

- Ativos eletrofilicamente: sua ação microbiocida ocorre por um ataque / substituição eletrofílica através de um componente da célula microbiana (se comportando como uma base de Lewis) no composto biocida (se comportando como um substrato e um ácido de Lewis). Este componente da célula pode ser o grupo amina 
de um aminoácido. Exemplos de compostos biocidas desta classe são: formaldeídos, glutaraldeídos, acroleína e composto N-halo-alquil-tio;

- Formadores de quelato: competem com os cátions metálicos necessários para o funcionamento do metabolismo da célula. Exemplos de compostos biocidas desta classe são: ditiocarbamato, piritionato de zinco, mercaptopiridina, sais de cobre e prata.

- Ativos na membrana: atuam através da adsorção na membrana citoplasmática do microorganismo (NEU, 1996), causando mudanças na sua estrutura. Exemplos de compostos biocidas desta classe são: álcoois, fenóis, carbanilidas, dibenzamidinas, biquanidas, sais quaternários de amônio (SQA) e outros componentes ativos com caráter catiônico (VIEIRA; RIBEIRO, 2006).

Ativos na membrana: As superfícies externas das células dos microorganismos universalmente carregam cargas negativas (proveniente dos fosfolipídios), frequentemente estas cargas são estabilizadas pela presença de cátion divalentes como $\mathrm{Mg}^{2+}$ e $\mathrm{Ca}^{2+}$ (GIBERT; MOORE, 2005). Estes cátions estão associados com a membrana citoplasmática, sendo assim, não é tão surpreendente que muitos agentes microbianos sejam catiônicos e apresentem uma grande afinidade pelas células microbianas. Frequentemente biocidas catiônicos requerem uma forte carga positiva e uma região hidrofóbica para interagir com a superfície da célula, ou seja, com a membrana citoplasmática. Esta interação é suficiente para perturbar o crescimento e se utilizados em concentrações adequadas é suficiente para causar e perda de fluidos pela membrana e causar a morte da célula. Assim estes compostos vêm sendo chamados de "agentes ativos na membrana" ou como "detergentes biológicos", reconhecendo sua especificidade no modo de ação. Aprofundando um pouco mais no modo de ação, as membranas são compostas primariamente de proteínas entremeadas por uma matriz de lipídeos, com o formato de uma bicamada. As proteínas podem ser totalmente transversais aos dois lados da bicamada (proteínas integrais) ou associada com um lado específico (periférica). Muitas destas proteínas da membrana existem, a fim de, manter a integridade estrutural da membrana, enquanto outras são funcionais e estão associadas com catabolismo, transporte celular e biossíntese da parede e compostos extracelular (toxinas). A funcionalidade destas proteínas é regulada pela hidrofobicidade do meio e da vizinhança pelos fosfolipídios. Então cada proteína é rodeada por 
fosfolipídios específicos que interagem com a proteína e agrega a proteína uma conformação funcional. A bicamada de lipídeos é, além disso, estabilizada por cátions bivalente como $\mathrm{Ca}^{2+}$ e $\mathrm{Mg}^{2+}$. Agentes microbianos catiônicos são relativamente hidrofóbicos, mas interagem inicialmente com a parede da membrana deslocando e substituindo estes cátions divalentes. Esta substituição ocasiona uma perturbação geral na bicamada de lipídeos da membrana levando a um generalizado e progressivo vazamento do material citoplasmático para o meio.

$\mathrm{Na}$ figura 29, os segmentos (a-f) mostram que há adsorção progressiva da parte positiva do quaternário (cabeça polar) nos fosfolipídeos ácidos da membrana com o aumento da exposição / concentração de SQA. Isso leva à diminuição da fluidez da bicamadas e a criação de vazios hidrofílicos na membrana. A função da proteína é perturbada com uma eventual lise (quebra) da célula e solubilização de fosfolipídeos e proteínas em micelas SQA / fosfolipídio. A micrografia inserida mostra a formação de vesículas fora da membrana causada pela presença do SAQ.

A nível molecular, a ação envolve uma associação do nitrogênio quaternário carregado positivamente com os grupos ânionicos de ácido-fosfolipídios da membrana (Figura. 29b). A cadeia hidrofóbica do SQA se interpenetra (MARCOTTE; BARBEAU; LAFLEUR, 2005) na parte hidrofófica da membarna (Figura. 29b,c). Assim, em baixa concentração do SQA (proximo do MIC - concentração inibitória mínima), a interação aumenta a pressão na superfície exposta da membrana, ocasionando uma diminuição da fluidez e na temperatura de transição de fase. A membrana sofre uma transição de líquido para o estado líquido cristalino e perde muitas de suas funções osmorregulatórias e fisiológicas (Figura. 29d). O centro da membrana diminui em hidrofobicidade e os fosfolipídios tendem para um arranjo mais estável de forma hexagonal. Nas concentrações de uso, os SQAs formam agregados micelares mistos que solubilizam componentes hidrofóbicos da membrana (figura. $29 \mathrm{e}, \mathrm{f}$ ). 

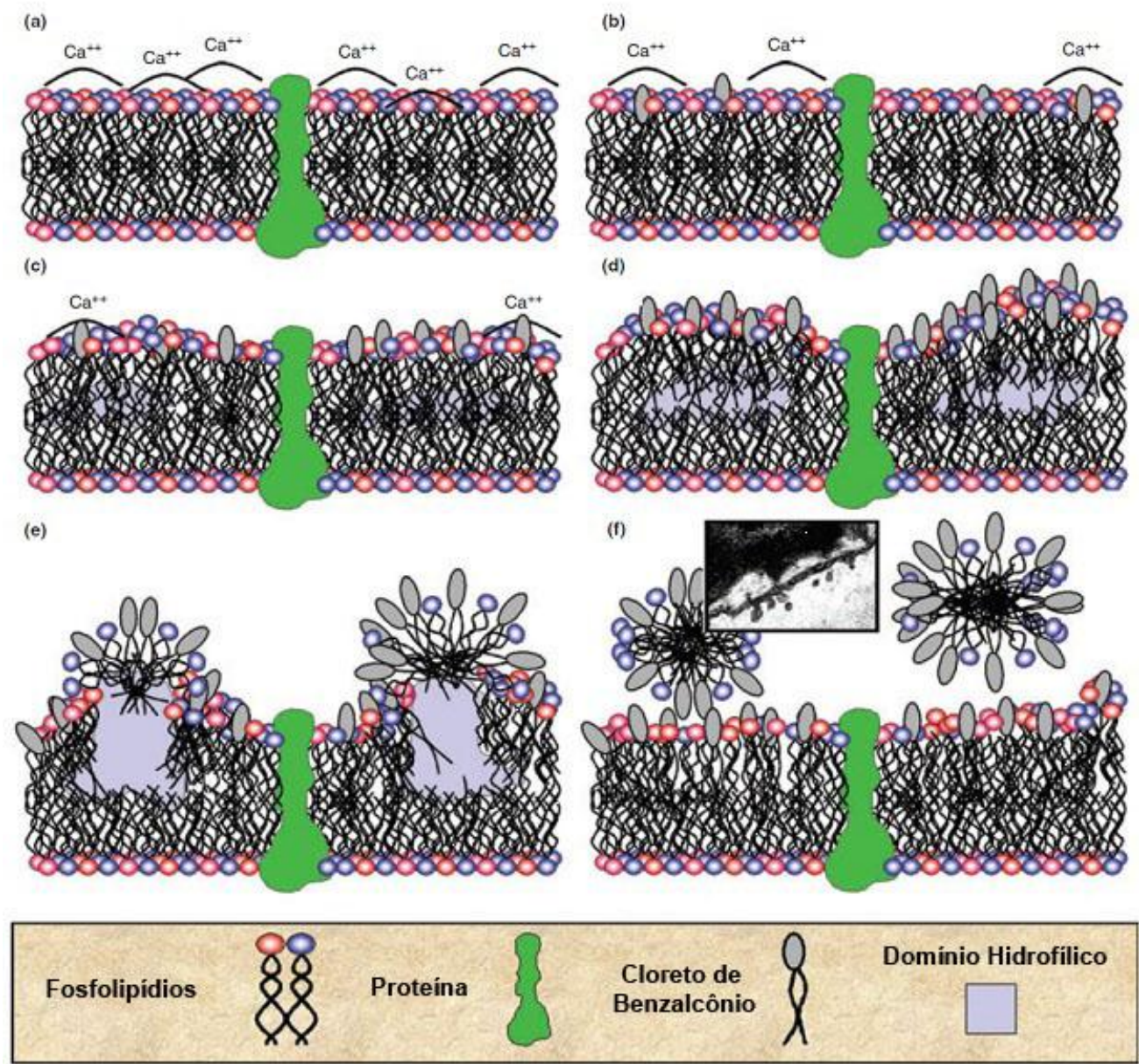

Figura 29 - Mecanismo de ação de um biocida quaternário de amônio (adaptada de GILBERT, 2005).

Concentrações baixas de SQA se ligam firmemente aos radicais aniônicos da superfície da membrana, causando a perda da capacidade osmorregulatória e o vazamento de íons $\mathrm{Na}^{+}$e $\mathrm{K}^{+}$. Concentrações médias de SQA alteram atividades fisiológicas da célula como respiração, transporte de solutos e biossíntese na parede. Concentrações altas usadas em formulações biocidas, no entanto, matam as células por solubilização das membranas e liberação de todo conteúdo citoplasmático, por isso a designação "detergente biológico".

Os compostos quaternários de amônio disponíveis comercialmente possuem diferente comprimento da cadeia alquílica, com distribuições graxas (n) e graus de saturação C-C diferentes, os quais afetam a atividade microbiana. 
Para bactérias gram-positivas e leveduras, a cadeias alquílica que maximiza a atividade biocida dos $S Q A$, possui distribuição graxa $n=12-14$, enquanto que para gramnegativas a distribuição graxa é da ordem de $n=14-16$. SQA com distribuição graxa < $n=4$ e $>n=18$, não apresentam atividade microbiana (GIBERT; MOORE, 2005).

\subsection{TINTAS}

O mais antigo uso conhecido de tintas data de aproximadamente 23.000 a.C. na forma de pinturas em cavernas próximo de Lascaux na França (CIULLO, 1996). Estes desenhos eram feitos com pastas de óxido de ferro e manganês, os quais eram misturados com água em pilões formando uma argamassa bruta. Ovos, gordura animal e tutano eram utilizados como possíveis ligantes. Cinzas de madeira, siderita (carbonato de ferro), e cal podiam ser utilizadas como matéria-prima primária, as quais, combinadas originavam cores como preto, vermelhas e amarelas.

Os egípcios foram os primeiros povos a usar as tintas como proteção, ao invés de, apenas com propósito decorativo, usando óxido de chumbo como preservante para madeira. Hoje em dia as tintas podem ser divididas de acordo com sua funcionalidade ou aplicação final em: Revestimentos arquitetônicos e Revestimentos industriais.

- Revestimentos Arquitetônicos: são essencialmente as tintas utilizadas para proteção e decoração de interiores e exteriores de edifícios. Estas tintas são frequentemente aplicadas em paredes, madeira, concreto e tijolo, para evitar a absorção de umidade, inchaço e degradação enquanto fornece um filme durável, flexível e decorativo;

- Revestimentos Industriais: são as tintas usualmente aplicadas em superfícies metálicas ferrosas e não ferrosas. A exposição de superfícies ferrosas ocasiona a formação de uma camada oxidada na superfície. Essas tintas industriais têm como base em sua formulação substancias como óleo de linhaça e pigmentos anticorrosivos como cromato de zinco. 
A formulação de uma tinta deve conter matérias-primas de basicamente quatro principais categorias: ligantes, solventes, pigmentos e aditivos (CIMINELLI, 1989):

Ligantes: é o suporte principal para formação do filme. O ligante polimérico é a chave para formação de um filme contínuo. Este literalmente liga e mantêm os componentes e pigmentos unidos. Exemplos: resinas acrílicas, resinas vinílicas, resinas poliuretanas, resinas estireno-butadieno, resinas epóxi e resinas de celulose.

Solventes: são necessários em tintas líquidas para solubilizar ou dispersar os ligantes. O solvente é perdido por evaporação durante a formação do filme. Tintas de látex utilizam água como solvente volátil. Exemplos: Solventes de hidrocarboneto ( $\mathrm{n}$ parafina, cicloparafina, tolueno, xileno e terpenos), solventes oxigenados (cetonas, ésteres, éteres de glicol e álcoois) e água.

Pigmentos: podem ser de dois tipos: corantes e de carga. Os pigmentos corantes são adicionados para transmitir a cor decorativa das tintas. Eles também ajudam a proteger o ligante contra a radiação UV, que degrada o filme. Os pigmentos de carga são minerais adicionados que modificam as propriedades do filme e reduzem custos. Exemplos: Pigmentos corantes: dióxido de titânio (branco), negro de fumo (preto), sulfeto de cádmio (amarelo), óxido de cromo (verde), etc.; Pigmentos de carga: calcita (carbonato de cálcio), talco, caulim, mica, barita (sulfato de bário) e dióxido de titânio.

Aditivos: é uma ampla categoria incluindo literalmente centenas de diferentes produtos químicos. Estes ingredientes não são usados em níveis maiores que cinco por cento do total de uma tinta. Mesmo com esta baixa concentração, eles trazem efeitos consideráveis para as propriedades de uma tinta. Exemplos: surfactantes, dispersantes, agentes reológicos, espessantes, plastificantes, biocidas, antiespumantes, inibidores de corrosão e estabilizantes UV. 


\subsection{AGENTES BIOCIDAS EM TINTAS}

O crescimento de microorganismos fototróficos, algas e cianobactérias, na tinta externa de edifícios podem causar descoloração e deterioração físico-química. As principais consequências deste crescimento são desfiguração, retenção de água, proliferação da colonização por algas, fungos e macrorganismos além de corrosão causada por ácidos orgânicos (ROY; THYE; NORTHWOOD, 1996). Estes problemas são importantes principalmente em países de clima úmido. Crispim e Gaylard (2005), Gaylard (2000) identificaram os tipos de algas e cianobactérias presentes na superfície das tintas de edifícios de cinco países da América Latina (Brasil, Argentina, Bolívia, México e Peru). Um total de 1363 de diferentes tipos de microorganismos foi identificado em 88 cidades. Dentre os microorganismos mais frequentes encontrados pode-se destacar: Synechocystis, Oscillatoria e Chlorella.

Um dos principais algicidas (LINDNER, 1997), utilizados em tintas externas de edifícios e outdoor é o diuron (DCMU-3,4- Diclorofenil-1,1-Dimetiluréia). Óxido de zinco, sais quaternários de amônio, brometo de sódio e sais de cobre possuem uma conhecida ação algicida após sua fixação em superfícies. (ALUM et al., 2008).

Uma grande variedade de compostos biocidas podem ser utilizados em tintas anti-incrustante para casco de navio, estudos demonstraram que apenas dois dos biocidas mais populares em uso Irgarol 1051 (s-Triazina) e Diuron são pouco lixiviáveis, enquanto 4,5-Dicloro-2-n-octil-4-isotiazolin-3-ona, diclofluanida, piritionato de zinco e clorotalonil lixiviam rapidamente (THOMAS et al., 2003). No entanto altas concentrações de s-Triazina e Diuron foram detectadas em regiões portuárias de vários países da Europa, podendo causar impacto ecológico nessas regiões, sendo seu uso banido em países como Reino Unido, Dinamarca e Suécia (KONSTANTINOU; ALBANIS, 2004 e DAHL; BLANCK, 1996). 


\section{Argilas organofílicas como agentes biocidas}

Pouco se encontrou na literatura da utilização de argilas modificadas (organofílicas) como agentes microbianos. Nano compósitos vem sendo desenvolvidos utilizando-se argilas modificadas com agentes microbianos. Fong; Simmons e PooleWarren (2010), He et al. (2006), desenvolveram nanocompósitos utilizando uma argila modificada com chlorhexidine acetate, o qual apresentou ação bactericida contra E. Coli e S. epidermidis.

Styan et al (2007) produziram um nanocompósito utilizando uma argila modificada com um composto quaternário de amônio, o qual apresentou ação bactericida contra S. epidermidis. Dizman et al (2007), Nigmatullin; Gao e Konovalova (2009) constataram que nanocompósitos produzidos utilizando-se argilas modificadas, com compostos quaternários de amônio, além das propriedades bactericidas ( $S$. aureus e E. coli) também apresentaram diminuição na lixiviação do biocida na superfície do nanocompósito.

Walters; Abbot e Isquith (1973) investigaram a utilização de sais quaternários de amônio para controle de algas em superfícies. SQA foram ancorados a superfície através da reação com um organosilicone, o qual permanece ligado à superfície, evitando sua lixiviação e inibindo o crescimento de algas.

No entanto, argilas em sua forma natural, ou seja, não modificadas, podem estimular o crescimento microbiano além de diminuir a eficácia de um biocida (Carbamato), quando o biocida e a argila natural estão presentes em meio aquoso (PEREIRA; VIEIRA; MELO 2000). 


\section{MATERIAIS E MÉTODOS}

\subsection{MATERIAIS}

\subsubsection{Argila sódica natural}

A argila utilizada foi uma bentonita sódica com o nome comercial de BentongelBentonisa $^{\circledR}$, fornecida pela empresa Bentonita do Norte S.A. - João Pessoa - PB.

\subsubsection{Sal quaternário de amônio}

Utilizou-se um sal quaternário de amônio fornecido pela empresa CLARIANT $\mathrm{S} / \mathrm{A}$, com nome comercial de Dodigen $2808^{\circledR}$. Trata-se de um cloreto de alquil benzil dimetil amônio, sendo este composto proveniente de um ácido graxo de coco, com distribuição graxa predominante C 12-14. No Dodigen 2808 a concentração de ativo quaternário é de $80 \%$ e o restante é solvente ( $20 \%$ de etanol).

\subsection{PREPARAÇÂO DA ARGILA ORGANOFÍLICA}

Argilas organofílicas são sintetizadas a partir da forma sódica da bentonita (VALENZUELA-DIAZ, 2001). Inicia-se com adição de $380 \mathrm{~g}$ de água em um béquer 500 $\mathrm{mL}$, em seguida adiciona-se lentamente $20 \mathrm{~g}$ de Bentogel ${ }^{\circledR}$ sob agitação mecânica (1500 rpm) por 20 minutos. Sob agitação mecânica $9,13 \mathrm{~g}$ de Dodigen $2808^{\circledR}$ é adicionado e agitado por 60 minutos. A dispersão é realizada e mantida à temperatura 
ambiente (por 24 horas). Em seguida a dispersão é filtrada através de um funil Buchner acoplado a uma bomba de vácuo, usando-se papel de filtro comum. O material sólido é filtrado e seco a $60{ }^{\circ} \mathrm{C}$ por 48 horas, em seguida o material é moído e peneirado em uma peneira com malha de 100 mesh $(0,149 \mathrm{~mm})$.

\subsection{CARACTERIZAÇÃO}

\subsubsection{Difração de Raios-X}

A difratometria de raios $X$ é usada para determinação da estrutura cristalina e do espaçamento interplanar (LEITE et al, 2008). Um feixe de raios direcionado sobre um material cristalino pode sofrer difração (interferência construtiva) como resultado de sua interação com uma série de planos atômicos paralelos, de acordo com a lei de Bragg. $O$ espaçamento interplanar é uma função dos índices de Miller e do(s) parâmetro(s) da rede cristalina, assim como da estrutura cristalina (CALLISTER, 1991).

Foi utilizado o método de varredura, que consiste na incidência dos raios $\mathrm{X}$ sobre uma amostra em forma de pó, compactado sobre um suporte. $\mathrm{O}$ aparelho utilizado é da marca Philips X'PERT MPD com radiação Ka do cobre $(1,54 \AA$ ), tensão de $40 \mathrm{KV}$, corrente de 40mA, tamanho do passo de 0,020 (20) e tempo por passo de $1 \mathrm{~s}$, pertencente ao Laboratório de Matérias-Primas Particuladas e Sólidos Não-Metálicos do Departamento de Engenharia Metalúrgica e de Materiais da Escola Politécnica da Universidade de São Paulo (LMPSol/PMT/EPUSP). 


\subsubsection{Análise Térmica: TGA}

Análise Térmica (WENDHAUSEN, 2009) é um termo que abrange um grupo de técnicas nas quais uma propriedade física ou química de uma substância, ou de seus produtos de reação, é monitorada em função do tempo ou temperatura, enquanto a temperatura da amostra, sob uma atmosfera específica, é submetida a uma programação controlada.

Termogravimetria (TG) é a técnica na qual a mudança da massa de uma substância é medida em função da temperatura enquanto esta é submetida a uma programação controlada. O termo Análise Termogravimétrica (TGA) e sua derivada (DTG) são comumente empregados

A analise térmica foi realizada em equipamento de termogravimetria (TG) da TA Instruments, modelo SDT Q600 do Departamento de Engenharia Química da Escola Politécnica da Universidade de São Paulo (PQI/EPUSP) e as condições de realização da analise foram:

Gás de purga: Nitrogênio.

Vazão do gás: $100 \mathrm{~mL} / \mathrm{min}$.

Taxa de aquecimento: $10^{\circ} \mathrm{C} / \mathrm{min}$.

Temperatura final: $1000^{\circ} \mathrm{C}$

\subsection{TESTE MICROBIOLÓGICO}

O Objetivo do teste microbiológico é a determinação da resistência ao crescimento de algas em película de tintas. Segui-se a metodologia ASTM D5589 - 97 (Standard Test Method for Determining the Resistance of Paint Films and Related Coatings to Algal Defacement). 


\subsubsection{Preparação das amostras de tinta}

Todo o estudo tomou por base a formulação de tinta cuja composição é apresentada na tabela 2. Durante todo o processo de preparo da tinta utilizou-se agitação mecânica em dispersor tipo Cowles (Miralles - B415) com haste dispersora.

Tabela 2 - Componentes da formulação de uma tinta imobiliária.

\begin{tabular}{|c|c|c|}
\hline Nome Comercial & Composição Química & Massa (\%) \\
\hline Água & $\mathrm{H}_{2} \mathrm{O}$ & 32,73 \\
\hline Nitrito Sódio & $\mathrm{NaNO}_{2}$ & 0,07 \\
\hline Emucryl D & Poliacrilato de sódio & 0,80 \\
\hline Mowilith LDM 7030 & Copolímero Acrílico & 0,40 \\
\hline Antarol & Emulsão óleo mineral & 0,20 \\
\hline Mowiplus FB 4053 & Amina policondensada & 0,10 \\
\hline Dioxido de Titânio & $\mathrm{TiO}_{2}$ & 8,00 \\
\hline Calcita M 325 & $\mathrm{CaCO}_{3}$ & 28,00 \\
\hline Agalmatolito M 325 & $\mathrm{Al}_{2} \mathrm{O}_{3}\left(4 \mathrm{SiO}_{2}\right)\left(\mathrm{H}_{2} \mathrm{O}\right)$ & 13,00 \\
\hline Amoniaco & $\mathrm{NH}_{3}$ & 0,10 \\
\hline Mowilith LDM 7020 & $\mathrm{Copolímero} \mathrm{Acrílico}_{20}$ & 1,50 \\
\hline Butil Glicol & $\mathrm{C}_{6} \mathrm{H}_{14} \mathrm{O}_{2}$ & 0,70 \\
\hline Texanol & $\mathrm{C}_{12} \mathrm{H}_{24} \mathrm{O}_{3}$ & 0,30 \\
\hline Mowilith VP 6170 & Copolímero Estireno-Acrílico & 11,00 \\
\hline Total & & 100 \\
\hline
\end{tabular}

Primeiramente pesa-se parte da água (80\%) em um vaso metálico com capacidade para 5 litros, inicia-se com uma agitação lenta (650 rpm) e então os seguintes componentes são adicionados: Nitrito de sódio; Emucryl D; Mowilith LDM 7030 e Antarol L. Após completa homogeneização, adiciona-se lentamente Mowiplus FB 4053. 
O sistema é mantido sob agitação por mais 10 minutos a 800 rpm, enquanto isso se pesa em um segundo recipiente a carga inorgânica: Dióxido de titânio; Calcita M 325 e Agalmatolito M 325. Em seguida, toda a carga inorgânica é adicionada lentamente na dispersão aquosa, ajusta-se a agitação entre 800 e 1200 rpm conforme necessário. Após completa homogeneização do sistema, adiciona-se amoníaco. Após 10 minutos de agitação, adiciona-se Mowilith LDM 7020 (lentamente), Butil Glicol e Texanol.

Ajusta-se a rotação entre 1200 rpm e 1800 rpm (conforme necessário) e após 15 minutos ou completa homogeneização do sistema adiciona-se Mowilith VP 6170. Após 10 minutos de agitação verifica-se a viscosidade, ajustando-a para um valor entre $130 \mathrm{e}$ $140 \mathrm{KU}$ (Brookfield - RVT - Synchro Lectric /Iscometer - fuso 7, $50 \mathrm{rpm}$ e $25^{\circ} \mathrm{C}$ ). $\mathrm{O} \mathrm{pH}$ também deve ser verificado e ajustado para 8,5. Após o preparo da tinta, alíquotas da tinta foram aditivadas com diferentes dosagens de Bentonita sódica, Dodigen 2808 e argila organofílica.

\subsubsection{Preparo dos Cupons de prova}

Primeiramente realiza-se a pintura dos cupons de prova (cartão inerte de $240 \mathrm{~g} / \mathrm{m}^{2}$ ). Aplica-se duas demãos da tinta, com intervalo de 24 horas entre as demãos, utilizando-se um pincel de $1 \frac{1}{2}$ polegada, sobre um dos lados do cupom de prova, tomando-se o cuidado de formar uma película uniforme. Após a aplicação, secar por sete dias em ambiente com troca de ar à $25 \pm 2{ }^{\circ} \mathrm{C}$ e umidade de $60 \pm 5 \%$. Durante a secagem manter o cupom de prova na posição horizontal. Após secagem, proceder ao fracionamento de metade dos cupons de prova, em quadrados de $35 \mathrm{~mm}$, denominados de corpos de prova. A outra metade dos cupons de prova deve prosseguir para o teste de lixiviação. 


\subsubsection{Teste de Lixiviação dos Cupons de Prova}

Colocou-se metade dos cupons de prova pintados no tanque de lixiviação. Estes devem ser lixiviados individualmente para evitar a ação de interferentes.

O tanque de lixiviação (figura 30 ) foi confeccionado em acrílico com medidas gerais: base $570 \mathrm{~mm} \times 280 \mathrm{~mm}$, altura frontal $450 \mathrm{~mm}$ e altura traseira $780 \mathrm{~mm}, 20$ compartimentos individuais, fluxo de água em cada compartimento, volume (aproximado) de cada compartimento $2.000 \mathrm{~mL}$.

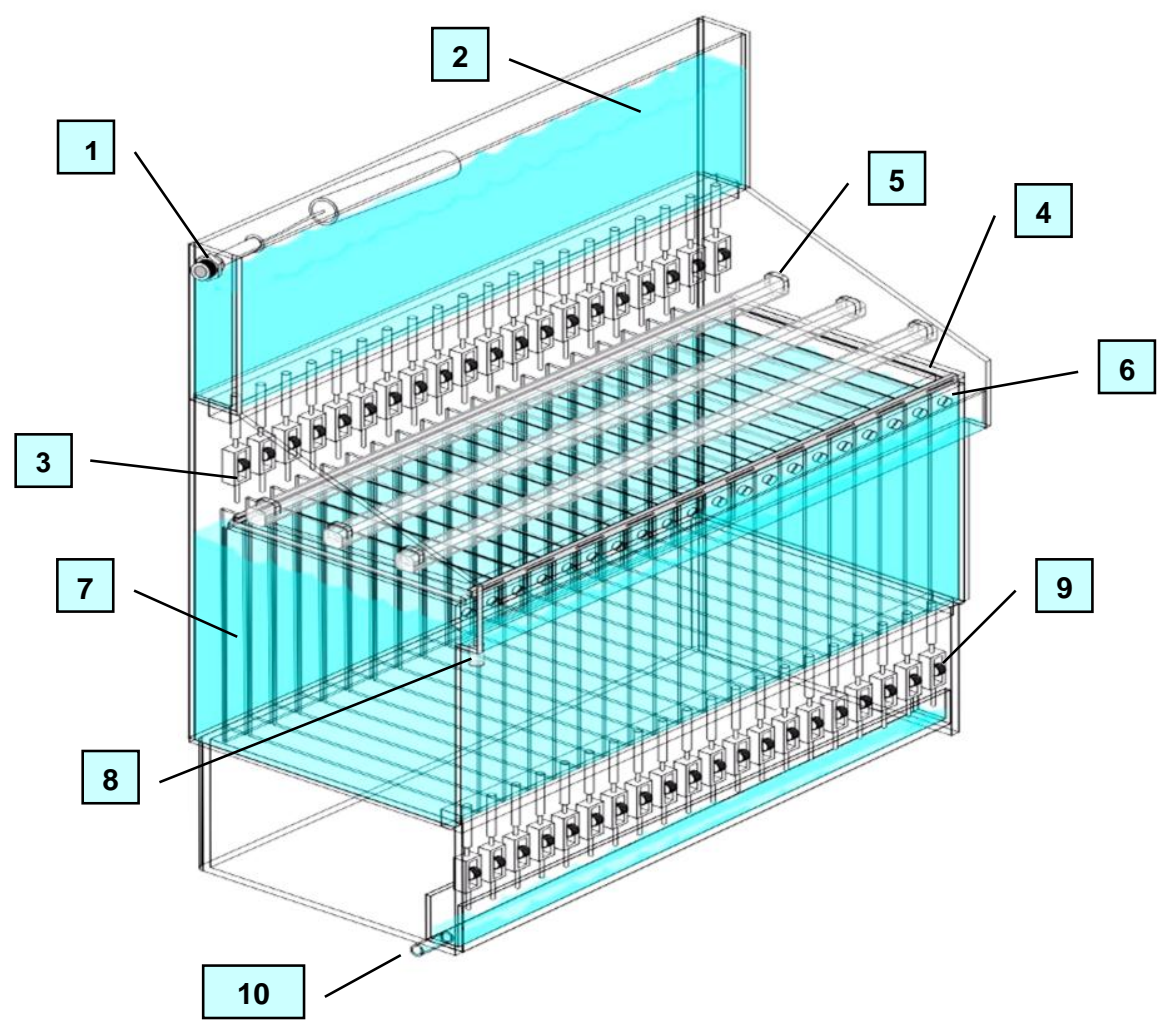

Figura 30 - Esquema geral do tanque de lixiviação.

1- Entrada geral de água e boia de controle de nível;

2- Reservatório da água de entrada;

3- Controle individual da entrada de água de cada compartimento; 
4- Varal para fixação dos cupons de prova;

5- Bastão (opcional) para fixação de cupons de prova de substratos rígidos;

6- Saída de água superior de cada compartimento;

7- Compartimento individual para cada cupom de prova;

8- Saída geral de água;

9- Controle individual de esgotamento de água de cada compartimento;

10- Saída para esgotamento de água;

Alimenta-se o tanque de lixiviação com fluxo contínuo de água potável de 500 $\mathrm{mL} /$ hora em cada compartimento e taxa de troca de 4 horas. Os cupons de prova devem ser lixiviados por 24 horas. Após a lixiviação, secá-los por dois dias à temperatura ambiente. Após este período, fracionar o cupom de prova em quadrados de $35 \mathrm{~mm}$, denominados de corpos de prova. (Se após a lixiviação ocorrerem danos visíveis na película, o cupom de prova deve ser descartado, pois a película não resistiu à lixiviação).

\subsubsection{Preparação do Inóculo (suspensão mãe)}

Repicou-se as cepas das algas Phormidium cebenense, Trentepohlia odorata, Chlorella sp e Scenedesmus quadricauda, separadamente, em meio de cultura líquido. Em ambiente estéril, preparou-se a suspensão de algas. Determinou-se a concentração de algas na suspensão, utilizando-se câmara de Neubauer (ASTM D5589 - 97) e ajustou-se para 1,0 × 10 $0^{6}$ microorganismos por $\mathrm{mL}$, diluindo-se, caso necessário, com solução salina. Se a concentração estiver abaixo deste nível, utilizam-se mais algas para o preparo da suspensão. Efetuou-se esta operação separadamente para cada cepa de alga. Após o ajuste da concentração, misturou-se proporcionalmente as quatro espécies de algas e chamou-se esta mistura de inóculo ou suspensão mãe ou ainda "pool" de algas. 


\subsubsection{Inoculação e Incubação}

Para o método de inoculação e incubação primeiro funde-se o meio de cultura BBM (Bold's Basal Medium), homogeneizar e distribuir de $20 \mathrm{~mL}$ a $30 \mathrm{~mL}$ do meio de cultura em uma placa de Petri. Deixar solidificar e esfriar até $25 \pm 2^{\circ} \mathrm{C}$ em superfície plana. Com o auxílio de uma pinça estéril, colocar o corpo de prova na placa, centralizando-o com a face pintada para cima. Transferir o inóculo "pool de algas" para um frasco esterilizado com aplicador de spray. Aplicar um filme da suspensão de algas, certificando-se que toda superfície possui um filme homogêneo e não está supersaturada. Certificar-se que a mesma quantidade de inoculo seja aplicada nas diferentes placas de Petri. Incubar, sem inverter as placas, durante 21 dias à temperatura de $25 \pm 2^{\circ} \mathrm{C}$, com $\geq 85 \%$ de umidade e com ciclos constantes de 12 horas de luz fluorescente branca e 12 horas de escuridão, efetuando-se avaliação do crescimento das algas. Os testes são realizados em triplicata.

As avaliações do crescimento das algas sobre o corpo de prova foram feitas a olho nu e de acordo com a tabela abaixo. A presença ou tamanho do halo de inibição não está diretamente associado ao desempenho do algicida, portanto, a medição do halo não é utilizada como critério de diferenciação no ensaio.

Tabela 3 - Observação do crescimento de algas sobre o corpo de prova.

\begin{tabular}{|c|l|}
\hline Nota & Observação \\
\hline 0 & Crescimento não detectado \\
\hline 1 & Crescimento menor que $10 \%$ da superfície do corpo de prova. \\
\hline 2 & Crescimento entre $10 \%$ a $30 \%$ da superfície do corpo de prova. \\
\hline 3 & Crescimento entre $30 \%$ e $60 \%$ da superfície do corpo de prova. \\
\hline 4 & Crescimento maior que $60 \%$ da superfície do corpo de prova. \\
\hline
\end{tabular}




\subsection{TESTE DE LIXIVIAÇÃO DE SUPERFÍCIE}

Inicialmente adicionou-se uma massa de biocida na tinta, tal que o teor de ativo quaternário de amônio final em $100 \mathrm{~g}$ de tinta seja de 5000ppm. Utilizaram-se estas 100 g da tinta para pintar a superfície interna de uma bandeja $(38 \times 53 \times 8 \mathrm{~cm})$ e consequente formação de um filme. Aplicaram-se duas demãos da tinta (todas $100 \mathrm{~g}$ de tinta devem ser consumidas) com intervalo de 24 horas entre as demãos, utilizando-se um pincel de $1 \frac{1}{2}$ polegada, tomando-se o cuidado de formar uma película uniforme. Após a aplicação, secar por 7 dias à temperatura ambiente.

Após a secagem adicionou-se na bandeja sobre a película de tinta $500 \mathrm{~g}$ de água destilada. Retiraram-se alíquotas desta água em contato com a película de tinta após 1 , 3,6 e 24 horas. O teor de sal quaternário de amônio foi quantificado nestas alíquotas.

\subsubsection{Quantificação do sal quaternário de amônio (ISO 2871-2, 2010)}

A matéria ativa catiônica (Sal quaternário de amônio) pode ser determinada por uma titulação de duas fases com uma solução padrão de lauril sulfato de sódio (0,004 M) usando indicador misto (aniônico e catiônico sendo brometo de dimídio e de azul de dissulfin VN 150, respectivamente).

$$
\begin{aligned}
& \text { Anion }^{-}{ }_{\text {aq }}+\text { Cátion }^{+}{ }_{\text {aq }} \text {--------------> }\left[\mathrm{AnCat}^{+}{ }^{+}\right. \text {org } \\
& \text { Indicador }^{+}{ }_{\text {aq }}(\text { Azul })+\text { Anion }^{-}{ }_{\text {aq }}(\text { excesso }) ~--------->\left[\operatorname{Ind}^{+} \mathrm{An}^{-}\right]_{\text {org }} \text { (Rosa) }
\end{aligned}
$$

Pesa-se uma massa conhecida do material catiônico, e dilui-se em um balão volumétrico de $1000 \mathrm{ml}$. Pipetar $25 \mathrm{ml}$ para uma proveta de $100 \mathrm{ml}$ com tampa. Adicionase a proveta $15 \mathrm{ml}$ de clorofórmio, $10 \mathrm{ml}$ de indicador misto e $10 \mathrm{ml}$ de água. Titular com lauril $(0,004 \mathrm{M})$ gota a gota, agitando após cada adição do titulante, até o ponto final, 
que é indicado pela mudança da coloração de clorofórmio de azul para azul acinzentado, na primeira gota que indique rosa constatará o excesso de titulante. Anotar o volume.

$$
\text { Matéria_Ativa_Catiônica }(\%, p / p)=\frac{V_{1} x M x F c x M o l x 4}{m_{1}}
$$

Onde:

$M=$ Molaridade da solução de lauril sulfato de sódio, em mol/L.

Fc = Fator de correção da solução de lauril sulfato de sódio

$\mathrm{V}_{1}=$ Volume de titulante em $\mathrm{mL}$.

$\mathrm{m}_{1}=$ Massa da amostra inicial, em $\mathrm{g}$.

$\mathrm{Mol}=$ Massa molecular da matéria ativa catiônica.

4 = fator de diluição de cálculo para \%. 


\section{RESULTADOS E DISCUSSÃO}

\subsection{DIFRAÇÃO DE RAIOS-X}

Pela lei de Bragg quando o material é exposto a um feixe monocromático de raios $X$, cada cela unitária é capaz de difratar os raios $X$. A equação abaixo demonstra a relação matemática entre o ângulo de difração do feixe de raios $X$ e a distancia interplanar existente entre dois planos.

$$
\text { n. } \lambda=2 . d \cdot \operatorname{sen} \theta
$$

Onde $\mathrm{n}$ é a ordem de difração do feixe, $\lambda$ é o comprimento de onda da fonte de radiação, $d$ é a distancia interplanar e $\theta$ é o ângulo de difração do feixe.

A DRX é muito útil para determinar o espaçamento das camadas de silicatos, pois sua morfologia de camadas empilhadas faz com que os raios- $X$ difratem mostrando a distância entre lamelas paralelas (distancia basal). A figura 31 mostra o difratograma da argila natural utilizada e seus respectivos planos de difração. 


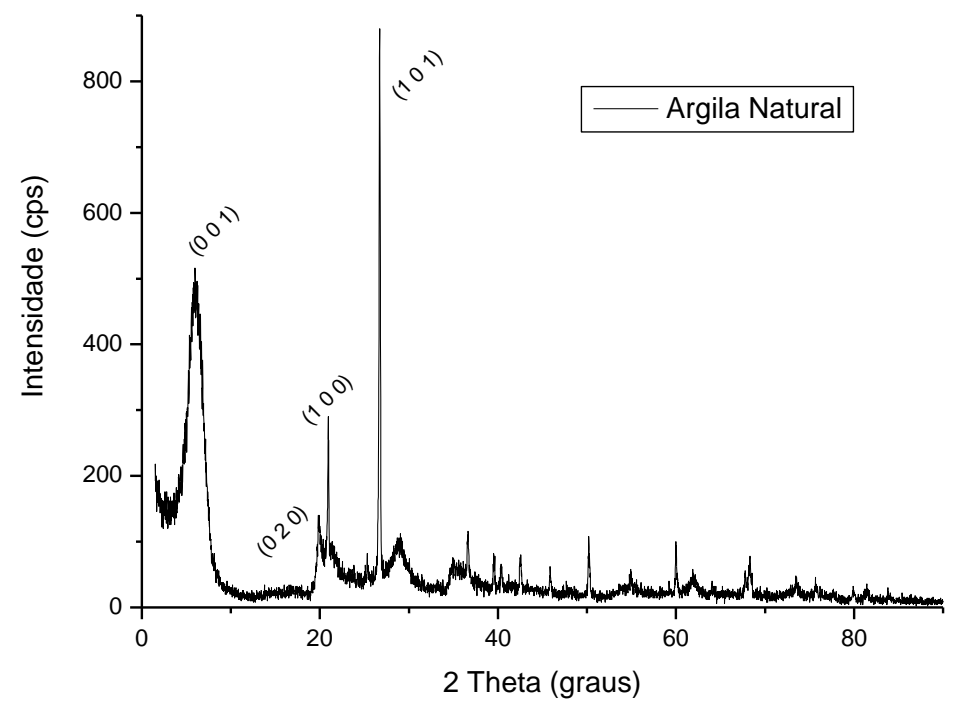

Figura 31 - Difratograma da argila natural

À medida que o argilomineral é intercalado, à distância interplanar aumenta. O aumento da distancia interplanar é percebido através dos picos de difração presentes no difratograma da argila organofílica (figura 32). Quanto menores os valores de $\theta$, maiores serão as distâncias interplanares.

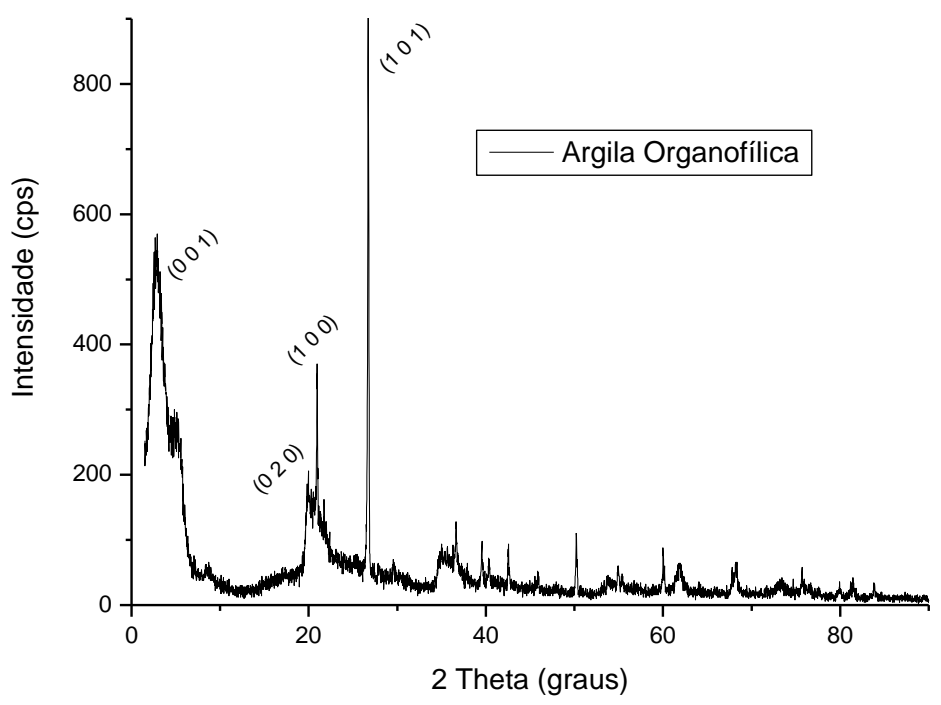

Figura 32 - Difratograma da argila organofílica 
O espaçamento basal do plano de difração (001) da argila natural quando comparada ao da argila organofílica aumentou de 1,45 nm para 1,83 e 3,23 nm (figura 33) mostrando que houve intercalação do sal quaternário de amônio.

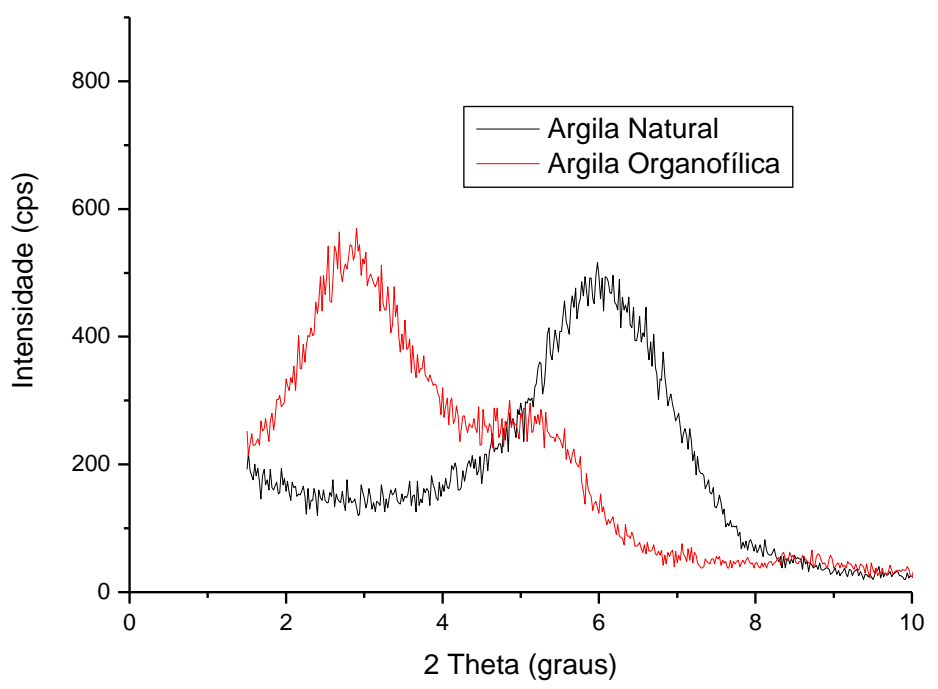

Figura 33 - Comparativo dos planos de difração (001) da argila natural e organofílica.

A presença de dois valores de distância basal após a intercalação pode ser atribuída à diferença da cadeia graxa do sal quaternário utilizado (C12-14), sendo o valor de 1,83 nm devido à intercalação da cadeia C12 e 3,23 a cadeia C 14 (Tabela 4).

Tabela 4 - Dados de Difração de Raios X da Argila Natural e Argila Organofílica.

\begin{tabular}{|c|c|c|c|c|c|}
\hline \multicolumn{3}{|c|}{ Argila Natural } & \multicolumn{3}{c|}{ Argila Organofílica } \\
\hline 2 Theta & $\mathbf{( h k l )}$ & $\mathbf{d}_{001}(\mathbf{n m})$ & 2 Theta & $\mathbf{( h k l )}$ & $\mathbf{d}_{001}$ (nm) \\
\hline 6,06 & 001 & 1,45 & 2,73 & 001 & 3,23 \\
\hline------ & ----- & ----- & 4,82 & 001 & 1,83 \\
\hline 19,86 & 020 & 0,44 & 19,87 & 020 & 0,45 \\
\hline 20,91 & 100 & 0,42 & 20,91 & 100 & 0,42 \\
\hline 26,79 & 101 & 0,33 & 26,70 & 101 & 0,33 \\
\hline
\end{tabular}




\subsection{ANÁLISE TÉRMICA: TGA}

A estabilidade térmica de compostos biocidas é muito importante, pois um agente microbiano instável termicamente pode degradar-se perdendo sua atividade biológica frente aos microorganismos.

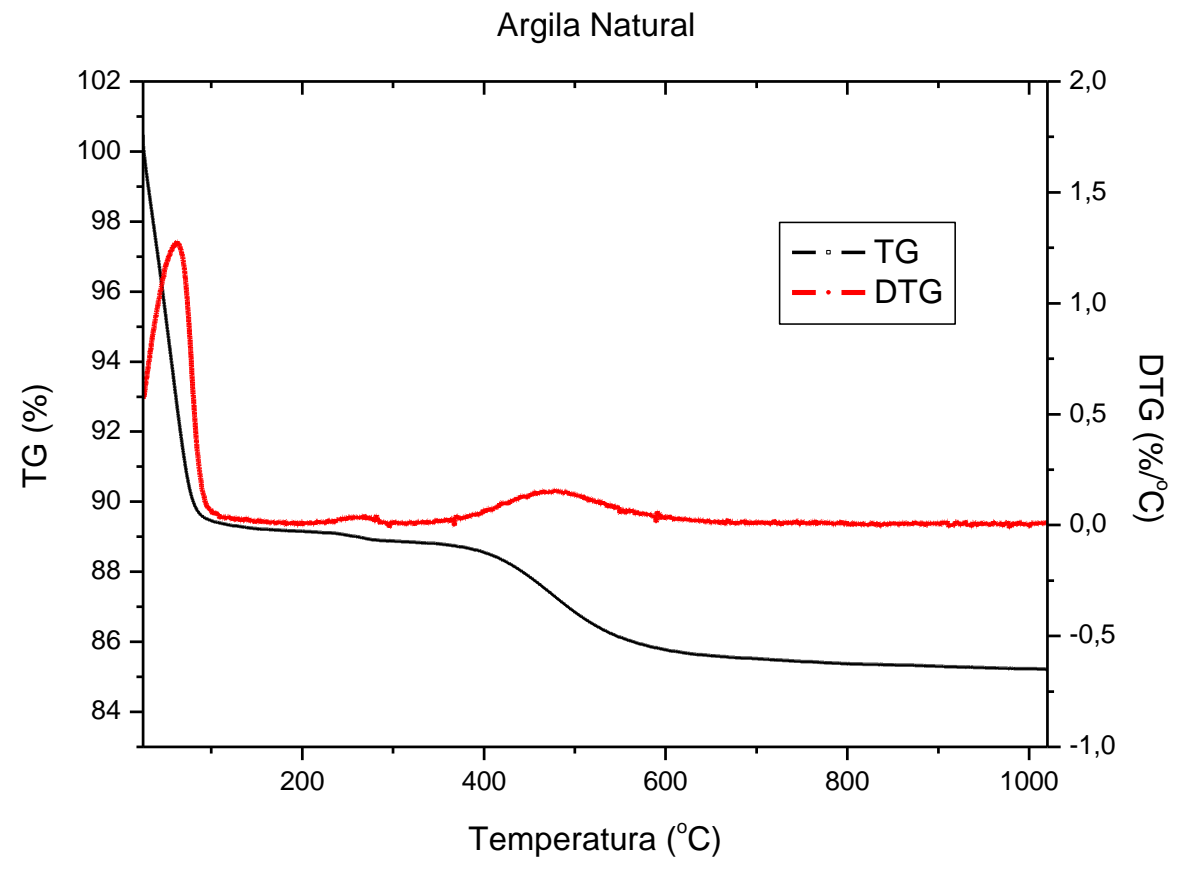

Figura 34 - Análise termogravimétrica da argila natural. 


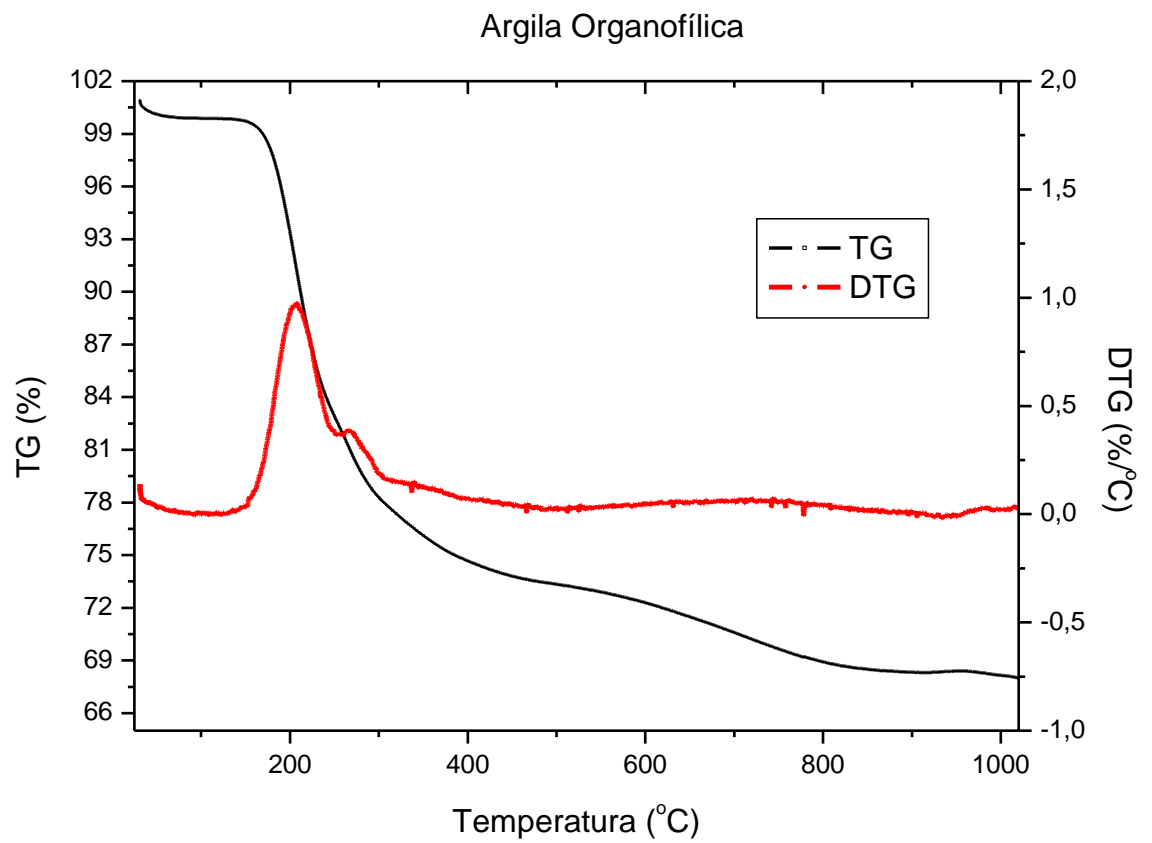

Figura 35 - Análise termogravimétrica da argila organofílica.

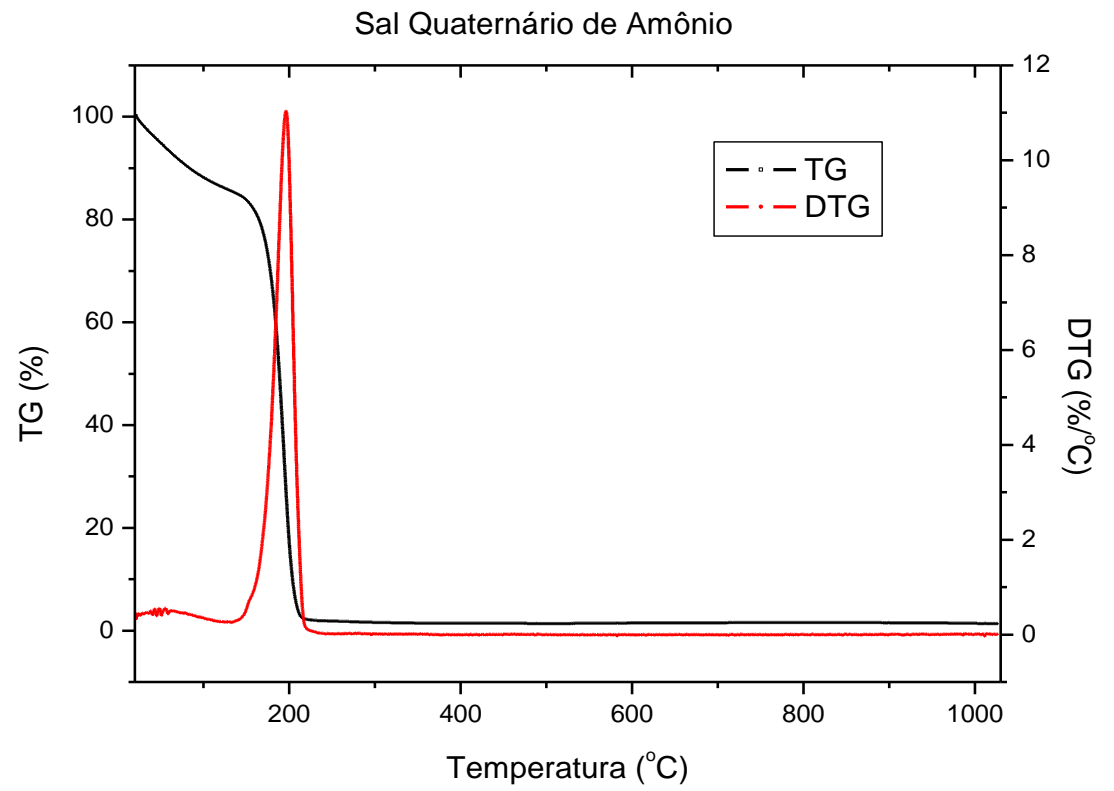

Figura 36 - Análise termogravimétrica do sal quaternário de amônio. 


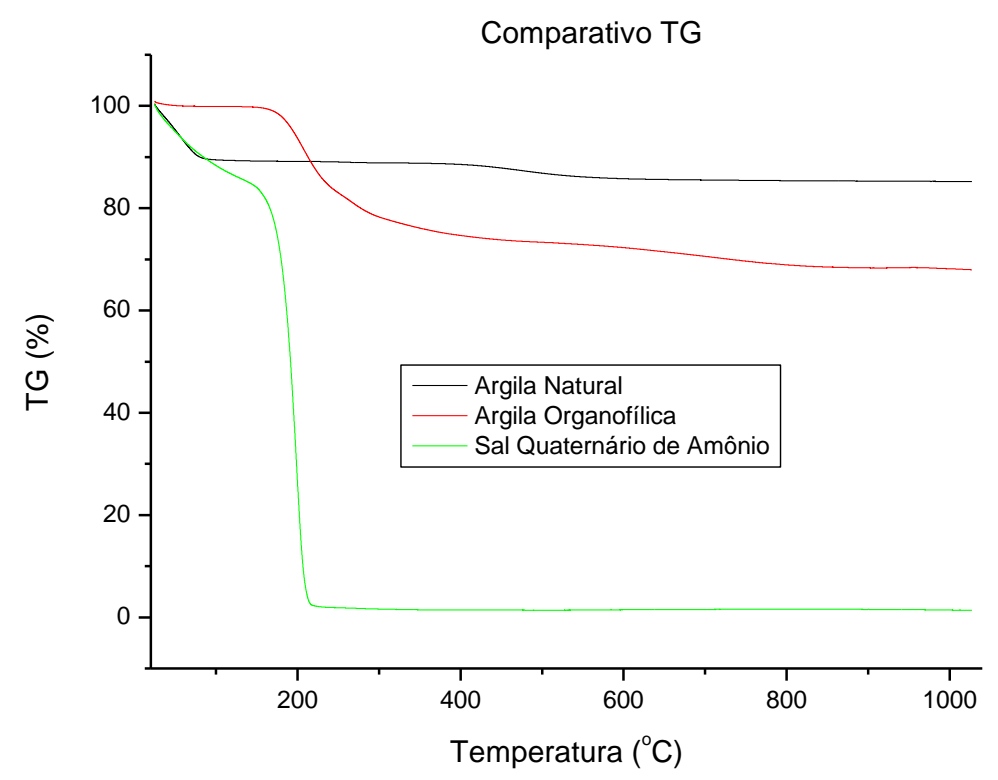

Figura 37 - Análise termogravimétrica comparativa.

Tabela 5 - Temperatura inicial $\left(T_{i}\right)$ e final $\left(T_{f}\right)$ de perda de massa (\%).

\begin{tabular}{|c|c|c|c|}
\hline Amostra & $\begin{array}{c}\text { Faixa de } \\
\text { Temperatura (ㅜㄷ) }\end{array}$ & $\begin{array}{c}\text { Perda em } \\
\text { Massa (\%) }\end{array}$ & Evento \\
\hline \multirow{3}{*}{ Argila Natural } & $25-100$ & 11,0 & $\mathrm{~A}$ \\
\cline { 2 - 4 } & $200-400$ & 0,5 & $\mathrm{~B}$ \\
\cline { 2 - 4 } & $400-600$ & 3,6 & $\mathrm{C}$ \\
\hline \multirow{2}{*}{ Argila Organofílica } & $25-100$ & 1,0 & $\mathrm{D}$ \\
\cline { 2 - 4 } & $200-450$ & 26,5 & $\mathrm{E}$ \\
\cline { 2 - 4 } & $450-600$ & 5,0 & $\mathrm{~F}$ \\
\hline Sal Quaternário de Amônio & $25-180$ & 18,0 & $\mathrm{G}$ \\
\cline { 2 - 4 } & $180-210$ & 82,0 & $\mathrm{H}$ \\
\hline
\end{tabular}

\section{Argila Natural:}

Evento A: região de secagem e desidratação, onde a água livre e/ou adsorvida é perdida, geralmente abaixo de $100^{\circ} \mathrm{C}$ (HEDLEY; YUAN; THENG, 2007); 
Evento B: região de pirólise da matéria orgânica usualmente acima dos $200^{\circ} \mathrm{C}$, devido à volatilização e/ou decomposição da matéria-orgânica;

Evento C: região da desidroxilação (perda das hidroxilas das camadas tetraédricas e octaédricas) da estrutura da argila entre 400 e $600^{\circ} \mathrm{C}$.

\section{Argila Organofílica:}

Evento D: região de secagem e desidratação, onde a água livre e/ou adsorvida é perdida, geralmente abaixo de $100^{\circ} \mathrm{C}$;

Evento $\mathrm{E}$ : região de decomposição da matéria orgânica, referente ao sal quaternário de amônio, presente na estrutura da argila, entre 200 e $450^{\circ} \mathrm{C}$;

Evento F: região da desidroxilação da estrutura da argila entre 400 e $600^{\circ} \mathrm{C}$.

\section{Sal Quaternário de Amônio:}

Evento G: região de secagem e evaporação do solvente até $180^{\circ} \mathrm{C}$.

Evento H: região de decomposição da matéria orgânica, referente ao sal quaternário de amônio, entre 180 e $210^{\circ} \mathrm{C}$

A perda de água livre e/ou adsorvida, na curva de TG, da argila organofílica é menor (1\%) que da argila natural (11\%). O sal quaternário de amônio apresenta uma perda de solvente (18\%) que está de acordo com o especificado pelo fabricante (18 - 22 $\%)$.

A perda de matéria-orgânica da argila organofílica (26,5\%) está de acordo com o balanço de massa teórico ( $20 \mathrm{~g}$ de argila natural $+7,3 \mathrm{~g}$ de sal quaternário de amônio $\approx$ $27,3 \mathrm{~g}$ de argila organofílica), sendo 26,73 \% de sal quaternário de amônio e 73,27\% de argila, confirmando que todo sal quaternário de amônio adicionado no processo de organofilização está na estrutura da argila.

Comparando a temperatura na qual ocorre a degradação do sal quaternário de amônio no Dodigen $2808\left(180-210^{\circ} \mathrm{C}\right)$ e na argila organofílica (200 - 450ํㅡ), observase que houve um ganho na estabilidade térmica do sal quaternário de amônio após o processo de organofilização. 
A desidroxilação da estrutura da argila não sofreu alterações significativas comparando-se a argila natural $(3,6 \%)$ e organofílica $(5,0 \%)$.

\subsection{TESTE MICROBIOLÓGICO}

De acordo com a metodologia descrita na norma ASTM D5589 - 97, realizou-se o teste microbiológico exploratório, utilizando-se apenas a argila organofílica, com o objetivo de verificar se a mesma possui ação microbiana, e sua concentração. No teste microbiológico comparativo verificou-se a ação microbiana da argila natural, da argila organofílica e do sal quaternário de amônio comparativamente.

\subsubsection{Teste exploratório.}

Avaliou-se o crescimento de algas na superfície dos corpos de prova, aos quais se aplicou tinta com diferentes dosagens de argila organofílica. As concentrações de sal quaternário de amônio (SQA) na tinta variaram de 0 a 2600 ppm (tabela 6). Metade dos corpos de prova foi submetida à lixiviação antes de se avaliar o crescimento microbiano.

Antes da lixiviação, o corpo de prova com a argila organofílica, nas dosagens dos testes E e F (1040 e 1300 ppm de SQA), apresentaram alguma ação biocida recebendo a nota 3 e 2 respectivamente. Na dosagem do teste $G$ antes da lixiviação (2600 ppm de SQA), não houve crescimento de algas recebendo nota 0 .

Depois da lixiviação as dosagens $\mathrm{E}$ e $\mathrm{F}$ perderam sua eficácia recebendo ambas a nota 4. A dosagem $G$, depois da lixiviação manteve a mesma nota 0 (tabela 6). Portanto na concentração de 2600 ppm de SQA na tinta, a argila organofílica pode ser utilizada como um algicida não-lixiviável para tintas (figura 38). 
Tabela 6 - Dosagem e escala de crescimento microbiano do teste exploratório.

\begin{tabular}{|c|c|c|c|c|c|c|}
\hline \multicolumn{2}{|c|}{ Dosagem de Argila Organofílica } & \multicolumn{5}{|c|}{ Lixiviação } \\
\cline { 1 - 2 } Teste & Massa (\%) & SQA (ppm) & \multicolumn{2}{|c|}{ Antes } & \multicolumn{2}{|c|}{ Depois } \\
\hline A & 0 & 0 & 4 & 4 & 4 & 4 \\
\hline B & 0,1 & 260 & 4 & 4 & 4 & 4 \\
\hline C & 0,2 & 520 & 4 & 4 & 4 & 4 \\
\hline D & 0,3 & 780 & 4 & 4 & 4 & 4 \\
\hline E & 0,4 & 1040 & 3 & 3 & 4 & 4 \\
\hline F & 0,5 & 1300 & 2 & 2 & 4 & 4 \\
\hline G & 1,0 & 2600 & 0 & 0 & 0 & 0 \\
\hline
\end{tabular}




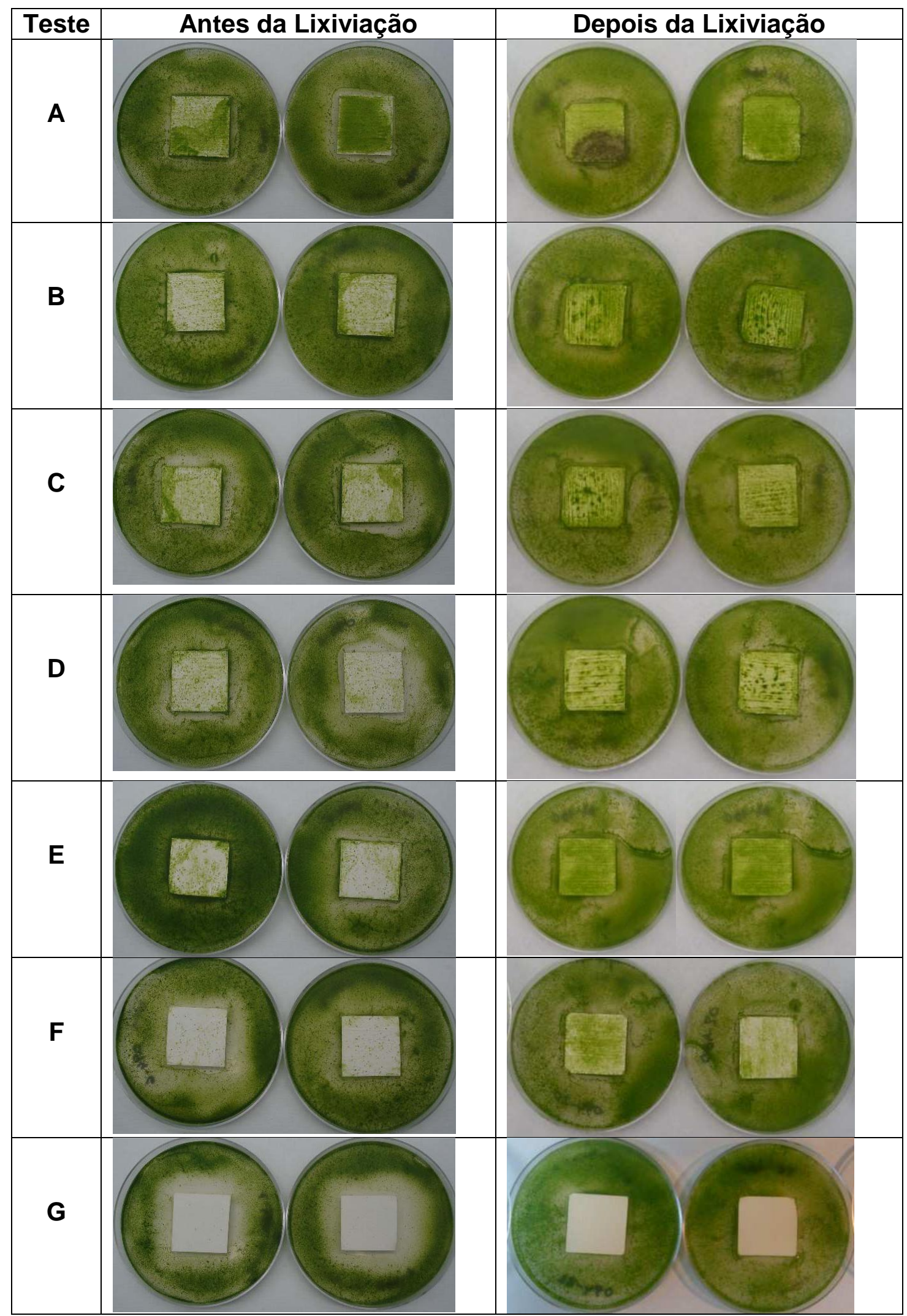

Figura 38 - Foto do crescimento de algas sobre o corpo de prova do teste exploratório. 


\subsubsection{Teste comparativo.}

No teste microbiológico comparativo avaliou-se em paralelo a ação microbiana da argila natural, da argila organofílica e do Dodigen 2808. As massas de produto (\%) e sua respectiva concentração de sal quaternário de amônio (SQA) em ppm dosados na tinta (utilizada para pintar os corpos de prova) estão na tabela 7.

Tabela 7 - Dosagem dos compostos adicionados na tinta para teste microbiológico.

\begin{tabular}{|c|c|c|c|c|c|c|}
\hline \multirow{2}{*}{ Teste } & \multicolumn{2}{|c|}{ Argila Natural } & \multicolumn{2}{c|}{ Argila Organofílica } & \multicolumn{2}{c|}{ Dodigen 2808 } \\
\cline { 2 - 7 } & Massa (\%) & SQA (ppm) & Massa (\%) & SQA (ppm) & Massa (\%) & SQA (ppm) \\
\hline H & 0 & 0 & 0 & 0 & 0 & 0 \\
\hline I & 0,38 & 0 & 0,38 & 1000 & 0,12 & 1000 \\
\hline J & 0,58 & 0 & 0,58 & 1500 & 0,19 & 1500 \\
\hline K & 0,77 & 0 & 0,77 & 2000 & 0,25 & 2000 \\
\hline L & 0,96 & 0 & 0,96 & 2500 & 0,31 & 2500 \\
\hline
\end{tabular}

O corpo de prova com a argila natural apresentou crescimento de algas em todas as concentrações avaliadas, antes e depois da lixiviação (nota 4 em todas as condições estudadas), comprovando que a argila natural não possui ação microbiana (tabela 8).

Para o teste utilizando o Dodigen 2808, antes da lixiviação não houve crescimento a partir da dosagem de 1500 ppm de SQA (nota 0). Depois da lixiviação houve crescimento em todas as dosagens estudadas (notas 3 e 4), mostrando que este composto é lixiviável (tabela 8)

No teste utilizando-se a argila organofílica ratificaram-se os resultados obtidos no teste exploratório (figura 39). Antes da lixiviação a partir da dosagem de 1000 ppm de SQA, observa-se alguma ação microbiana (nota 3), sendo que na dosagem de 2000 ppm não há crescimento (nota 0). Depois da lixiviação na dosagem de 2000 ppm de SQA não houve crescimento (nota 0 ). 
Portanto a argila organofílica sintetizada neste trabalho é um composto não lixiviável e pode ser utilizado como agente algicida para tintas a partir da dosagem de 2000 ppm de SQA (0,77\% em massa de argila organofílica, na tinta).

Tabela 8 - Escala de crescimento microbiano do teste comparativo.

\begin{tabular}{|c|c|c|c|c|c|c|}
\hline \multirow{2}{*}{ Teste } & \multicolumn{2}{|c|}{ Argila Natural } & \multicolumn{2}{c|}{ Argila Organofílica } & \multicolumn{2}{c|}{ Dodigen 2808 } \\
\cline { 2 - 7 } & \multicolumn{2}{|c|}{ Lixiviação } & \multicolumn{2}{c|}{ Lixiviação } & \multicolumn{2}{c|}{ Lixiviação } \\
& Antes & Depois & Antes & Depois & Antes & Depois \\
\hline H & 4 & 4 & 4 & 4 & 4 & 4 \\
\hline I & 4 & 4 & 3 & 4 & 4 & 4 \\
\hline J & 4 & 4 & 2 & 2 & 0 & 4 \\
\hline K & 4 & 4 & 0 & 0 & 0 & 3 \\
\hline L & 4 & 4 & 0 & 0 & 0 & 3 \\
\hline
\end{tabular}




\begin{tabular}{|c|c|c|c|c|c|c|}
\hline \multirow{3}{*}{ Teste } & \multicolumn{2}{|c|}{ Argila Natural } & \multicolumn{2}{c|}{ Argila Organofílica } & \multicolumn{2}{c|}{ Dodigen 2808 } \\
\cline { 2 - 7 } & \multicolumn{2}{|c|}{ Lixiviação } & \multicolumn{2}{|c|}{ Lixiviação } & \multicolumn{2}{|c|}{ Lixiviação } \\
\hline $\mathbf{H}$ & Antes & Depois & Antes & Depois & Antes & Depois \\
\hline I & & & & & & \\
\hline
\end{tabular}

Figura 39 - Foto do crescimento de algas sobre o corpo de prova do teste comparativo.

\subsection{TESTE DE LIXIVIAÇÃO DE SUPERFÍCIE}

No teste de lixiviação de superfície avaliou-se a presença de SQA em alíquotas de água, que estavam em contato com um filme de tinta (figura 40). Na tinta adicionouse Argila organofílica ou Dodigen 2808.

Considerando a relação massa/ volume, caso todo SQA seja lixiviável (tanto para o teste com a argila organofílica quanto para o Dodigen 2808), uma concentração de SQA de $1000 \mathrm{mg} / \mathrm{L}$ seria encontrado. 


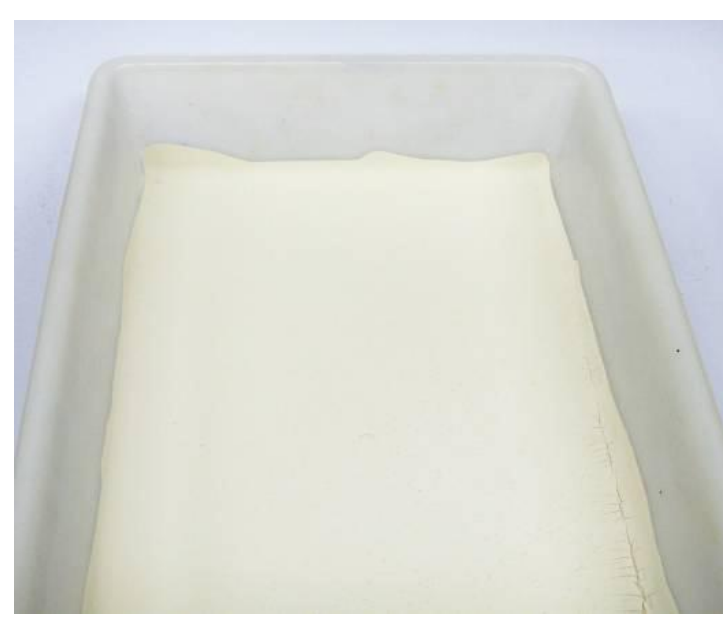

Foto $40-\mathrm{A}$

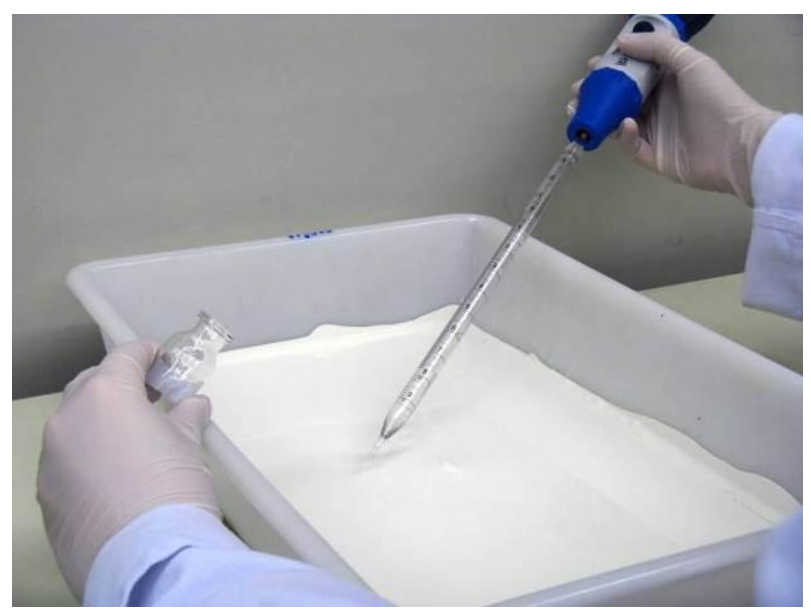

Foto $40-\mathrm{B}$

Figura 40 - Filme de tinta recoberto de água (foto 40-A); Retirada de uma alíquota de água para quantificação do SQA (foto 40-B).

Para a argila organofílica os resultados (tabela 9) mostram que, após 24 horas não foi detectado sal quaternário de amônio nas alíquotas de água que estavam em contato com o filme de tinta.

Para o Dodigen 2808, os resultados (tabela 9) mostram que após 24 horas encontrou-se uma concentração de $224 \mathrm{mg} / \mathrm{L}$ de sal quaternário de amônio na alíquota de água que estava em contato com o filme de tinta.

Tabela 9 - Quantificação do SQA no teste de lixiviação de superfície.

\begin{tabular}{|c|c|c|}
\hline \multirow{2}{*}{ Tempo (Horas) } & \multicolumn{2}{|c|}{ Sal Quaternário de Amônio (mg/L) } \\
\cline { 2 - 3 } & Argila Organofílica & Dodigen 2808 \\
\hline 1 & 0 & 164 \\
\hline 3 & 0 & 177 \\
\hline 6 & 0 & 190 \\
\hline 24 & 0 & 224 \\
\hline
\end{tabular}

Portanto o SQA proveniente da argila organofílica não é lixiviável, enquanto que o SQA proveniente do Dodigen 2808 é lixiviável, nas condições estabelecidas pelo teste. 


\section{CONCLUSÕES}

Com base na análise da revisão bibliográfica e resultados obtidos e demonstrados neste trabalho, pode-se concluir sobre os objetivos abordados na introdução deste trabalho.

De acordo com os resultados de difração de raios- $X$, o espaçamento basal da argila natural quando comparada ao da argila organofílica aumentou, mostrando que houve intercalação do sal quaternário de amônio e consequente organofilização da argila natural.

O resultado de análise térmica (TGA) do sal quaternário de amônio puro apresentou uma perda de solvente que está de acordo com o especificado pelo fabricante. A perda de matéria-orgânica da argila organofílica está de acordo com o balanço de massa, confirmando que o sal quaternário de amônio adicionado no processo de organofilização está na estrutura da argila. Comparando a temperatura de degradação do sal quaternário de amônio puro e na argila organofílica $\left(\approx 200^{\circ} \mathrm{C}\right.$ e $300^{\circ} \mathrm{C}$, respectivamente), observa-se que houve um ganho na estabilidade térmica do sal quaternário de amônio após o processo de organofilização.

O teste microbiológico exploratório mostrou que a argila organofílica pode ser utilizada como algicida não lixiviável para tintas, na faixa de dosagem compreendida entre 1300 e 2600 ppm de sal quaternário de amônio na tinta (0,5\% e 1,0\% em massa de argila organofílica, respectivamente).

O teste microbiológico comparativo mostrou que a argila natural não possui ação microbiana. O teste utilizando-se o sal quaternário de amônio puro mostrou que após a lixiviação este composto perde sua ação microbiana. $O$ teste microbiano utilizando-se a argila organofílica mostrou que após a lixiviação este composto na dosagem de 2000 ppm de SQA na tinta não perdeu sua ação microbiana $(0,77 \%$ em massa de argila organofílica na tinta).

O teste de lixiviação de superfície mostrou que o sal quaternário de amônio puro é lixiviável. No entanto o sal quaternário de amônio na estrutura da argila passa a ser não-lixiviável. 
Portanto a argila organofílica sintetizada neste trabalho é um composto não lixiviável e pode ser utilizado como agente algicida não-lixiviável para tintas.

\subsection{TRABALHOS FUTUROS}

Sugestões para pesquisas futuras:

- Sintetizar argilas organofílicas utilizando compostos com propriedades fungicidas;

- Avaliar as propriedades microbianas destes compostos frente a fungos;

- Análisar a intercalação (DRX) e análise térmica (TGA) destes compostos;

- Simular através de teste de lixiviação a hidrofobicidade destes compostos em filme de tintas. 


\section{REFERÊNCIAS BIBLIOGRÁFICAS}

ALUM, A.; RASHID, A.; MOBASHER, B.; ABBASZADEGAN, M. Cement-based biocide coatings for controlling algal growth in water distribution canals. Cement \& Concrete Composites. V. 30, p. 839-847, 2008.

AMERICAN SOCIETY FOR TESTING AND MATERIALS, Standard Test Method for Determining the Resistance of Paint Films and Related Coatings to Algal Defacement, ASTM D5589 - 97.

ARANHA, I. B.; OlIVEIRA, C. H.; NEUMANN, R., ALCOVER A. N.; LUZ, A. B. Caracterização Mineralógica de Bentonitas Brasileiras. Anais do XIX ENTMME (CDROM), Recife-PE, 2002.

BAILEY, S. W. Summary of recommendations of AIPEA nomenclature committee on clay minerals. American Mineralogist, V. 65, p. 1-7, 1980.

BALTAR C. A. M.; LUZ, A. B., Insumos Minerais para a Perfuração de Poços de Petróleo, CETEM/UFPE, Recife, cap. 2, p. 22-45, 2003.

BERGAYA, F.; THENG, B. K. G.; LAGALY, G. Handbook of Clay Science. Elsevier Ltd., Cap. 2, 2006.

BEVERIDGE, C.M. The effect of benzalkonium chloride concentration on nine species of marine diatom, Environmental Pollution. V.103, p. 31-36, 1998

BIOLOGY 1114, Membrana structure and function, Disponível em: < http://biol1114.okstate.edu > Acesso em 10 out. de 2011.

BOLSOVER, S. R.; HYAMS, J. S.; SHEPHARD, E. A.; WHITE, H. A.; WIEDEMANN, C. B. Biologia Celular. 2ª ed, Ed, Guanabara, Rio de janeiro, 2005.

BOTELHO, K. T., Síntese de argilas organofílicas e sua incorporação em polimerização in situ para a obtenção de nanocompósitos antichamas de poliestireno, Tese de mestrado, UFSC, Florianópolis, 2006. 
BROWN, G. Crystal structures of clay minerals and related phyllosilicates. Philosophical Transactions of the Royal Society of London, V. 311, p. 221-240, 1984.

CALLISTER, W. D. Materials Science and Engineering an Introduction. John Wiley \& Sons, Inc., New York, 1991.

CARASTAN, D. J. C. Obtenção e caracterização reológica de nanocompósitos de polímeros estirênicos. Tese de Doutorado, Escola Politécnica, USP, São Paulo, 2007.

CARAVAlho, H. F.; ReCCO-PIMENTEL, S. M. A Célula. 2ªed., Ed. Manole, São Paulo, 2007.

CHAPMAN, J. S. Disinfectant resistance mechanisms, cross-resistance, and coresistance, International Biodeterioration \& Biodegradation. V. 51, p. $271-276,2003$.

CIMINELLI, R. R. Parâmetros parta seleção e formulação de cargas minerais na industria de tintas. Anais do $1^{\circ}$ Congresso Internacional de Tintas, São Paulo, 1989.

CIULLO, P. A. Industrial minerals and their uses: a handbook and formulary, by Noyes Publication, USA, 1996.

COELHO, A. C. V.; SANTOS, P. S. Argilas especiais: argilas quimicamente modificadas - Uma revisão. Quimica Nova. Vol. 30, p. 1282-1294, 2007.

CRISPIM, C.A.; GAYLARD, C. C. Cyanobacteria and Biodeterioration of Cultural Heritage: A Review, Microbial Ecology. V. 49, p. 1-9, 2005.

DAHL, B.; BLANCK, H. Agent Irgarol 1051 on Periphyton Communities in Coastal Water Microcosms Marine Pollution Bulletin, V. 32, No. 4, p. 342-350, 1996.

DIZMAN, B.; BADGER, J. C.; ELASRI, M. O.; MATHIAS, L. J. Antibacterial fluoromicas: A novel delivery medium, Applied Clay Science V. 38, p. 57-63, 2007.

DNPM (Departamento Nacional de produção mineral) Bentonita. Súmario Mineral Brasileiro, 2009. 
FONG, N.; SIMMONS, A.; POOLE-WARREN, L.A. Antibacterial polyurethane nanocomposites using chlorhexidine diacetate as an organic modifier. Acta Biomaterialia. V. 6, p. 2554-2561, 2010.

FONSECA, M. G.; AIROLDI, C. Híbridos Inorgânicos-organicos derivados da reação de filossilicatos com organossilanos. Quimica Nova, Vol. 26, No. 5, p. 699707, 2003.

GAYLARDE, P. M.; GAYLARDE, C. C. Algae and cyanobacteria on painted buildings in Latin America International Biodeterioration \& Biodegradation. V. 46, p. 93-97, 2000.

GILBERT, P.; MOORE, L.E. A Review: Cationic antiseptics: diversity of action under a common epithet. Journal of Applied Microbiology, V. 99, p. 703-715, 2005.

HE, H.; YANG, D.; YUANA, P.; SHEN, W.; FROST, R. L. A novel organoclay with antibacterial activity prepared from montmorillonite and Chlorhexidini Acetas Journal of Colloid and Interface Science. V. 297, p. 235-243, 2006.

HEDLEY, C.B.; YUAN, G.; THENG, B.K.G. Thermal analysis of montmorillonites modified with quaternary phosphonium and ammonium surfactants, Applied Clay Science, V. 35, p. 180-188, 2007.

INTERNATIONAL ORGANIZATION OF STANDARDIZATION. ISO - 2871-2:2010 Surface active agents - Detergents - Determination of cationic-active matter content Part 2: Cationic-active matter of low molecular mass (between 200 and 500), 2010.

JÚNIOR, A. R. O., Obtenção de Nanocompósitos Polipropileno-Argila Compatibilizados com Organossilanos, Tese de Doutorado, Instituto de Química, UNICAMP, 2006.

KONSTANTINOU, I.K., ALBANIS, T.A. Worldwide occurrence and effects of antifouling paint booster biocides in the aquatic environment: a review, Environment International. V. 30, p. 235-248, 2004.

KONTA, J. Clay and man: Clay raw materials in the service of man. Applied Clay Science, V. 10, p. 275-335, 1995. 
KOZAK, M.; DOMKA, L.; SKRZYPCZAK, A. Adsorption of the quaternary ammonium salts on bentonite Physicochemical Problems of Mineral Processing. V. 36, p. 299-306, 2002.

LAGALY, G. Interaction of alkyamines with differents types of layered compounds. Solid State Ionics. V. 22, p. 43-51, 1986.

LEITE, I. F.; RAPOSO, C. M. O.; SILVA, S. M. L. Caracterização estrutural de argilas bentoníticas nacional e importada: antes e após o processo de organofilização para utilização como nanocargas, Cerâmica, V. 54, p. 303-308, 2008.

LINDNER, W. Studies on film preservatives: retention of DCMU in outdoor paints, Biofouling. V. 11, p. 179-189, 1997.

LUZ, A. B.; OLIVEIRA, C. H. Rochas \& Minerais Industriais: Usos e Especificações. CETEM, Rio de Janeiro, p. 217-230, 2005.

MARCOTTE, L.; BARBEAU, J.; LAFLEUR, M. Permeability and thermodynamics study of quaternary ammonium surfactants-phosphocholine vesicle system, Journal of Colloid and Interface Science. V. 292, p. 219-227, 2005.

MURRAY, H. H. Traditional and new applications for kaolin, smectite, and palygorskite: a general overview. Applied Clay Science, V. 17, p. 207-221, 2000.

NEU, T. R. Significance of Bacterial Surface-Active Compounds in Interaction of Bacteria with Interfaces, Microbiological Reviews, p. 151-166, Mar, 1996.

NIGMATULLIN, R.; GAO, F.; KONOVALOVA, V. Permanent, Non-Leaching Antimicrobial Polyamide Nanocomposites Based on Organoclays Modified with a Cationic Polymer Macromolecular Material Engineering. V. 294, p. 795-805, 2009.

PAIVA, L. B.; MORALES, A. R.; VALENZUELA-DIAZ, F. R. Organoclays: Properties, preparation and applications. Applied Clay Science. V. 42, p. 8-24, 2008.

PALMER, C. M.; MALONEY T. E. Preliminary screening for potential algaecides. The Ohio Jornal of Science. p. 55, 1955. 
PATEL, A. H.; SOMANI, R. S.; BAJAJ, H. C.; JASRA, R. V. Nanoclays for polymer nanocomposites, paints, inks, greases and cosmetics formulations, drug delivery vehicle and waste water treatment. Bull. Mater. Sci., Vol. 29, No. 2, p. 133-145, 2006.

PAULUS, W. Directory of microbicides for the protection of materials - A Handbook, ed. Springer, 2005.

PEREIRA, M. O.; VIEIRA, M. J.; MELO, L. F. The effect of clay particles on the efficacy of a biocide, Water Science and Technology, V. 41, No 4-5, p. 61-64, 2000.

PEREIRA, K. R. O.; RODRIGUES, M. G. F.; VALENZUELA-DIAZ, F. R. Síntese e caracterização de argilas organofílicas: comparação no uso de dois métodos Revista Eletrônica de Materiais e Processos, V. 2, p. 01-08, 2007.

PUROHIT, A.; KOPFERSCHMITT-KUBLER, C.; MOREAU, C.; POPIN, E.; BLAUMEISER, M.; PAULI, G. Quaternary ammonium compounds and occupational asthma. Int Arch Occup Environ Health. V. 73, p. 423-427, 2000.

ROSSI, A. C. R. Estudo de biofilmes e células planctônicas de bacillus cereus frente a um sanificante à base de composto quaternário de amônio utilizado na industria de laticinius, Dissertação (mestrado), Escola Superior de Agricultura Luiz de Queiroz, Piracicaba-SP, 2008.

ROY, S. K.; THYE, L.; NORTHWOOD, D. O. The evaluation of paint performance for exterior applications in Singapore's tropical environment, Building and Environment. V. 31, p. 477-486, 1996.

STYAN, K.; ABRAHAMIAN, M.; HUME, E.; POOLE-WARREN L. A. Antibacterial polyurethane organosilicate nanocomposites. Key Engineering Materials; V. 342343, p. 757-60, 2007.

SOLOMONS, T. W. G. , FRUHLE, C. B. , Química Orgânica, $7^{a}$ edição, LTC - Livros Técnicos e Científicos Editora S. A ., Rio de Janeiro, 2001.

SOUZA SANTOS, P. de Ciência e tecnologia de argilas, ed. Edgard Blucher Ltda, São Paulo-SP, V.1, $2^{\circ}$ ed, 1992. 
SOUZA SANTOS, P. de Ciência e tecnologia de argilas, ed. Edgard Blucher Ltda, São Paulo-SP, V.2, $2^{\circ}$ ed, 1992.

SOUZA SANTOS, P. de Ciência e tecnologia de argilas, ed. Edgard Blucher Ltda, São Paulo-SP, V.3, $2^{\circ}$ ed, 1992.

TEIXEIRA-NETO, E.; TEIXEIRA-NETO, A. A. Modificação química de argilas: desafios científicos e tecnológicos para obtenção de novos produtos commaior valor agregado. Química Nova. V. 32, p. 809-817, 2009.

THENG, B.K.G. The Chemistry of Clay-Organic Reactions. $1^{\circ}$ ed., John Wiley \& Sons, New York, 1974.

THOMAS, K. V.; MCHUGH, M.; HILTON, M.; WALDOCK, M. Increased persistence of antifouling paint biocides when associated with paint particles, Environmental Pollution. V.123, p. 153-161, 2003.

UNITED STATES GEOLOGICAL SURVEY (USGS), Open-File Report 01-041. Disponível em: < http://www.usgs.gov/ > Acesso em 10 out. de 2011.

VALENZUELA-DIAZ, F. R. Preparation of organophilic clays from a brazilian smectitic clay, Engineering Materials. V. 189-191, p. 203-207, 2001.

VALENZUELA-DIAZ, F. R; SANTOS, P. S.; SANTOS, H. S. A importância das argilas industriais brasileiras, Química industrial, V 42, p 31-33, 1992 a.

VALENZUELA-DIAZ, F. R; SANTOS, P. S.; SANTOS, H. S. A importância das argilas industriais brasileiras, Química industrial, V 42, p 33-37, 1992 b.

VIANA, P. R. M. Flotação de espodumênio, microclina, quartzo e muscovita com coletores aniônicos, catiônicos, anfotéricos e mistura de coletores. Tese (doutorado), Departamento de Engenharia Metalúrgica e de Minas da Universidade Federal de Minas Gerais, Belo Horizonte - MG, 2006.

VIEIRA J. C. L.; PINTO, C.A.; VALENZUELA-DIAZ, F. R.; BUCHLER, P. M. Síntese de argilas organofilicas visando seu uso no controle ambiental de resíduos de fenol. Anais do $46^{\circ}$ congresso de cerâmica São Paulo, p 1685-1695, 2002. 
VIEIRA, D. B.; RIBEIRO, A. M. Cationic lipids and surfactants as antifungal agents: mode of action, Journal of Antimicrobial Chemotherapy, V. 58, p. 760-767, 2006

WALKER, J. R. L.; EVANS, S. Effect of Quaternary Ammonium Compounds on some Aquatic Plants, Marine Pollution Bulletin. V. 9, p. 136 - 137, 1978.

WALTERS, P. A.; ABBOTT, E. A.; ISQUITH, A. J. Algicidal Activity of a SurfaceBonded Organosilicon Quaternary Ammonium Chloride, Applied Microbiology. p. 253-256, 1973.

WENDHAUSEN, P. A. P. Análises Térmicas, Apostilas, Universidade Federal de Santa Catarina (UFSC), 2009. 